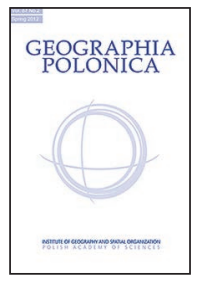

\title{
THE EARLY MEDIAEVAL SLAV-GERMAN BORDER (LIMES SORABICUS) IN THE LIGHT OF RESEARCH INTO Y-CHROMOSOME POLYMORPHISM IN CONTEMPORARY AND HISTORICAL GERMAN POPULATIONS
}

\author{
Mariusz Kowalski \\ Institute of Geography and Spatial Organization \\ Polish Academy of Sciences \\ Twarda 51/55, 00-818 Warsaw: Poland \\ e-mail: mar.kow@twarda.pan.pl
}

\begin{abstract}
In the 8th century, the first political boundary between Germany (the land of the Franks) and the Slav people - known as Limes Sorabicus - followed the line of the Rivers Elbe and its tributary the Saale. In later centuries this was breached under the influence of an eastwards political expansion of Germany also characterised by developing German colonisation in that same direction (of the so-called Ostsiedlung). The consequence was for German regional communities to take shape to the east of the old Limes Sorabicus. Alongside the emigrants from the west, further participants in the process where autochthonous Slavs and Balts. This mixed origin of the new communities arising is revealed in historical accounts, but also via the results of scientific analyses of various profiles. The genetic research carried out to date supports the above contention, as well as a conclusion that the zone around the old Limes Sorabicus, despite its running through the centre of what is today an ethnically-German area, continues to represent a separation of populations whose ancestors are mainly of distinct origins.
\end{abstract}

\section{Key words}

Germans $\cdot$ Slavs $\bullet$ eastward colonisation $\bullet$ origin of populations $\bullet$ relict boundaries $\bullet$ genetic research

\section{Introduction}

Research on borders is proving a source of ever-greater interest (see Kałuski, 2017; Więckowski, 2019), primarily given the diverse issues that surround their existence. While some work for example concerns borders as phenomena that are the obvious manifestation of political activity (e.g., Scott, 2018; Kolosov \& Więckowski, 2018); other studies analyse a border's impact on broadsphere socioeconomic issues (e.g. Siwek, 2012; Więckowski, 2018; Stepanova, 2019). It seems likely that these kinds of analyses will assume still-greater significance in the future, given the way that our era (or generational 
cycle) is seemingly characterised by isolationist tendencies (Kowalski, 2019a). Indeed, the latter manifesting in an enhanced significance for administrative boundaries (including the borders of states) have been seen very clearly in the reactions of countries - and the societies living in them - to the COVID-19 pandemic.

A feature of border research is the phenomenon of the relict border (as recently noted by Mariusz Kowalski (2019b), as well as the research project entitled Granice Polski jako zasoby - pomiędzy dziedzictwem a produktem turystycznym or 'Polish borders as a resource - between heritage and a tourist product ${ }^{\prime 1}$ ). What are involved here are borders that have lost their administrative (political) functions even as they remain noticeable in space, given the way they continue to draw a line between distinct phenomena of a cultural nature (Hartshorne, 1933; Sobczyński, 2008). A relict border may be assigned to the "informal borders" category where it is distinguishing criteria of a non-legal (and non-administrative) nature that are met. And, like borders of every type, these may also be linear, or in the nature of zones (Rykiel, 1984; Weiher, 1991; Bański, 2010). More widely, the term relict border can be assigned, not only to cultural frontiers, but also to all informal boundaries that represent the heritage of an old political (and administrative) system. Hence the reference to the notion in the present article also, albeit here in the context of genetic differentiation in the human population.

In the 7th century, the Frankish authorities set their boundaries along the Rivers Elbe and Saale, in this way delimiting their state (which was later East-Frankish, and hence German) from the territories ruled over by Slavic tribes. Thus, 7th-century chronicler Fredegar referred to the Saale as the boundary

1 The project entitled Granice Polski jako zasoby - pomiędzy dziedzictwem a produktem turystycznym (grant from the National Science Centre No. NCN 2018/29/B/HS4/02417), as pursued at the Institute of Geography and Spatial Oranisation of the Polish Academy of Sciences under the direction of Marek Więckowski, considers relict borders an important element of cultural heritage (https://www.igipz.pan.pl/ project_en/events/3_6953.html). separating the land of the Sorb people from the Frankish province of Thuringia. This frontier was termed Limes Sorabicus (or 'the Sorbian March'), on account of the Slav people referred to. The prolongation of the same borderland further to the north went by the name of Limes Saxoniae. For several centuries, this was a frontier of a political nature (indeed through to the 10th century in the south and the 12th in the north) (Leciejewicz, 1989). However, work by both historians and archaeologists makes it clear that there was Slav settlement west of Elbe and Saale rivers in the area of Upper Franconia, Saxony (Wendland) and Thuringia (Strzelczyk, 1981). For that reason, it is more accurate to refer to a zone associated with Limes Sorabicus that extended along the Elbe and Saale and was penetrated by both Slav and German settlement.

The significance of Limes Sorabicus as a former boundary between the German and Slav worlds can be made very clear thanks to contemporary toponymy - i.e. in place-names. While west of the line (or more properly zone), names of Slavic origin are not present, to its east they account for a considerable - or even prevalent - share. And this is true of both large cities (Berlin, Chemnitz, Dessau, Dresden, Leipzig, Rostock, etc.), and small localities (such as Belitz, Dobin, Jellen, Krakow, Rosin, Tarnow and Teldau in Mecklenburg). As can be seen from these examples, the names of the localities concerned often have very characteristic endings (suffixes) in the: "-tz", "-ow", "-au" and "in" groups (Kleiner Atlas der Siedlungsnamen Deutschlands, Fig. 1), with these seen to correspond to the Polish-language endings "-ce", "-ów", "-wa" and "-in" respectively.

A similar phenomenon is revealed where anthroponymy is concerned, given that in Germany's eastern part there are many inhabitants bearing surnames of Slavic origin (Berger, 1999; Immel, 2006; Kowalski \& Śleszyński, 2012). One such is Piefke, which can be set against such Polish surnames as Piwek, Piwko and Piwka. In this case, things have gone so far that Piefke actually enjoys the status of an ethnophaulism - being 

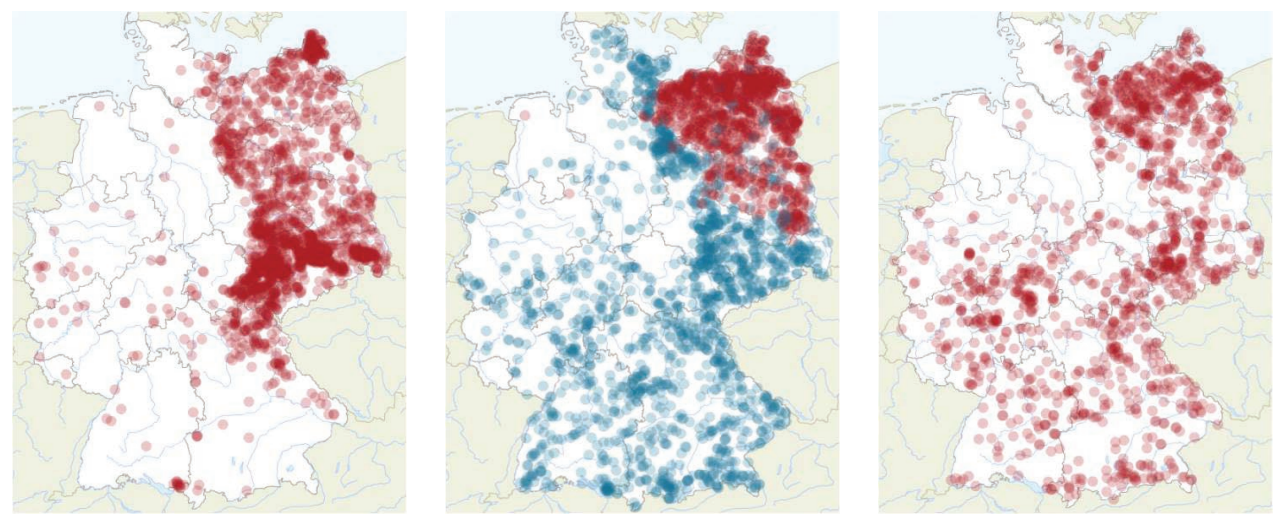

Figure 1. Names of localities in Germany, on the left ending in "-tz", in the middle in "-ow" (red) or "-au" (blue), and on the right in "-in"

Source: Kleiner Atlas der Siedlungsnamen ...

used by the Austrians to refer to their German neighbours to the north, above all those hailing from Prussia (Mally, 1974).

Later, a period of eastward German colonisation and states' territorial expansion led to a breached status of the original border and the incorporation into Germany of extensive areas east of the two rivers. Literature relating to the Middle Ages sees these areas referred to as Germania Slavica (Strzelczyk, 1976a; Lübke, 1998; Ingrao \& Szabo 2008).

The mixing with Slav peoples as a consequence of the eastward influx of Germans (and with Baltic peoples in East Prussia) combined with the influence German culture and state structure were able to exert to generate new, effectively-Eastern German communities that came to be looked upon as Brandenburgers, Pomeranians, Silesians, Prussians, Mecklenburgers and Saxons (Sakson, 1994; Leśniewska, 2004; Piskorski, 2005; Cetwiński, 2011; Lübke, 2014). Most of these later came together to co-create Prussian society in the modern understanding of that term.

Furthermore, this new ethnically-German area would subsequently be characterised by a new socioeconomic quality that the literature on modern times and modernity has termed Ostelbien (East Elbia) (Weber, 1993; Kortus, 2004). This reflects the different conditions here in regard to, for example, the feudal system (Junkers privileges, serfdom and corvee of peasants), culture, politics (characterised by conservatism), as well as distinctiveness in terms of language (with new German dialects noticeably under Slavic influence) and system of settlement (villages of Rundling, Angerdorf, Reihendorf and Gutsdorf types). From a German perspective, the above features were seen as emphasising the distinct nature of Prussia, when set against Germany's western and southern Länder (or regions) (Salmonowicz, 1987; Reif, 1994; Hardt, 1999; Wagner, 2003; Eddie, 2008 Filip, 2012; Siatkowski, 2015; Engelmann, 2016; Meinecke, 2016; Moeller van den Bruck, 2016).

Given the above circumstances, the zone around the old Limes Sorabicus has remained a socioeconomic and cultural boundary. Indeed, it is not possible to rule out the idea that post-reunification observations regarding differences of a similar kind between the so-called Ossie and Wessie in Germany (e.g. Jiménez, 2015) actually reflect or hark back to some of the conditioning that characterised the Ostelbien (von Wedel, 2011; Hawes, 2018).

To a greater or lesser extent the phenomena referred to leave Eastern Germans looking more similar to their neighbours further east (Poles, Czechs and Slovaks) - even as the latter 
are of course Slav nations, and assigned along with the Ostelbien to Europe's "East" when it comes to the concept of the economic dualism present in early modern Europe (Sosnowska, 2004; Małowist, 2010).

In this context a question arising relates to the ancestral origin of "new" regional grouping within German society. To what extent did these reflect influxes from the west, and to what extent did these arise from among local people? A process still observable in the 20th century whereby Slav and Balt peoples (e.g. Mazurians and Prussian Lithuanians) undergo Germanisation inclines the researcher to a hypothesis that the ancestry of the native population might lie largely in Eastern German regional communities. In the case of East Prussia, historical demographers have been able to demonstrate that the Germans there had most ancestors of Baltic derivation (Kossert, 2004; Jurkat, 2005). Equally, where the German Ostelbien overall was concerned, Walter Kruse (1929) used physical anthropology research to estimate that Slav ancestors accounted for a 43\% share (albeit with Mikołaj Rudnicki (1936) regarding that figure as an underestimation, given Kruse's main focus on the urban population). Irrespective of that, all of the regions under consideration have been shown to have experienced, not only German settlement, but also a process of Germanisation of the local Slav people, with the latter participating jointly (along with the German incomers from the west) in the shaping of new Eastern German regional communities (Kaczmarczyk, 1953; Strzelczyk, 1976b; Piskorski, 1990; Lübke, 2014; Kirsch, 2004).

Proceeding on the assumption that this phenomenon occurred on a broad scale, we would see the zone of the old Limes Sorabicus as representing a relict border within the ethnically-German area that is actually of a genealogical nature, given the way it may continue to separate descendants of the original Germans (i.e. Saxons, Thuringians and Franks) from people whose forebears were very largely of Slav or Balt origin. While a colonisation process put new conditions in place, the autochthonous origin of some part of the population might also have played its key role in shaping cultural and socioeconomic features of the Eastern Germans that were distinct, and have in some cases remained so through to the present day.

In the context of the research problem as formulated above, it becomes clear just how important analysis of the results of genetic testing might prove to be.

\section{Genetic research in Germany}

Post-War, it was rare for any work on the genetic diversity present in Germany to be carried out. This was very much a reflection of researchers' natural unwillingness to return to the population biology and genetics so misused under the Nazis (Krawczak et al., 2008). However, more recent years have yielded new perspectives when it comes to researching communities, nations, ethnic groups and even interested families, given the development of molecular genetics and new discoveries associated with it.

Human genetic information is encoded on the two strands of DNA. While that supermolecular assembly involves a total of some six billion chemical buildings blocks spread across 23 pairs of chromosomes (in each nucleated cell), these still boil down to just four types of nucleobase, i.e. adenine (A), cytosine $(C)$, guanine $(G)$ and thymine $(T)$. This representation of a "genetic alphabet" is thus one formed solely from many different combinations of the four letters A,C, G and T, with the genetic code being based around the ordering of these bases. Hence the nature of the gene as a stretch (and sequence) of bases along the DNA strand that code for the production of a given protein.

Without more major consequences, it is possible for small differences in the genecoding sequences along the strands of DNA to arise, to the extent that two randomlyselected human beings will theoretically differ at around a million places on average along the 2 sets of DNA strands each containing 3 billion of the aforesaid "letters". 
This average picture is complicated by the second characteristic that, in general, the less closely-related two people are, the greater the number of single-letter differences allowing a distinction to be drawn between them. This is then a property that allows both individuals' origins and their levels of relatedness to be assessed (Reich, 2019).

One method by which to take advantage of the above regularity involves the study and comparison of the so-called autosomal DNA - i.e. the part of the human genome present on the 22 pairs of chromosomes other than the so-called $X$ and $Y$ chromosomes determining sex. Individuals within a population (or ethnic group) may show considerable similarities of their autosomal DNA, even as they differ quite markedly from the individuals making up other populations(Sykes, 2007; Lavryashina et al., 2016; Krūmina et al., 2018).

However, further opportunities have been opened up by the discovery of the "genetic marker" phenomenon involving characteristic fragments of DNA relating to a single set of features and conferring the same profile on those who share a bloodline. This allows for the identification of fixed haplogroups, which is to say similar sets of feature in the genomes of all those who inherited them from a common ancestor. Female-line (mother-daughter) inheritance for example applies to DNA haplogroups in cell mitochondria (of the so-called mtDNA), given that a father's genetic material plays no part in supplying these organelles to the fertilised embryo. Father-son (male-line) inheritance is in turn a matter for haplogroups present in Y-DNA (i.e. on the so-called Y-chromosome that ensures male offspring).

Different human populations around the world experienced the impacts of genetic so-called "bottlenecks", as populations at certain points declined to critical minimum size, and the number of genealogical lines was in this way limited very drastically. This explains the emergence and existence of just several tens of fundamental male or female (Y-chromosome or mtDNA) haplogroups that unite millions of human beings today with a single ancestor who proved able to survive through the time of the aforementioned "bottleneck", and to reproduce. The haplogroups have been assigned letters A, B, C, D and so on, in reference to a succession of mutations taking place through the millennia, with sub-groups (subclades) within these haplogroups that arise being denoted by numbers and lower-case letters (hence R1a, I2a and so on). The haplotype is then the combination of Y-chromosome or mtDNA markers that characterise a given individual, with many people of a given haplotype being assigned to the relevant haplogroup.

It emerges that the genes representing haplogroup markers have no direct connection with a person's physical appearance (not least race) - as that is determined by different genes. There is also no direct link with ethnicity (this being a matter for the cultural environment to shape). Despite that, in line with conditioning of various different kinds, given haplogroups (and the subclades thereof) are not distributed at random through different human populations, but are in fact variants characteristic for ethnic origins, to the extent that a person's origins may be predicted by reference to them (Balanovsky et al., 2008; Krawczak et al., 2008; Rębała et al., 2012; Juras, 2012; Handschuh et al., 2016; Watson, Berry, \& Davies, 2018).

Analyses taking advantage of the above new-approach techniques have already yielded many interesting observations. Where differences in autosomal DNA are concerned, a focus has been on the core-Slav inhabitants of Eastern Germany known as the Lusatian Sorbs. For obvious reasons, these people are seen to be closest to the Poles and Czechs in terms of their genetic identity. Perhaps counter-inuitively, another Western Slav nation - the Slovaks - are found to be slightly further away from Lusatian Sorbs in genetic terms than are the German inhabitants of Leipzig. The latter are shown to have autosomal-DNA features intermediate between those in the Western Slav population of Lusatian Sorbs and the Western Germanic populations comprising Germans more generally, 
as well as the Dutch (Veeramah et al., 2011) The fact that the people of Leipzig represent a transitional population may reflect a mixed ancestry.

Work on mtDNA polymorphism has in turn been done in Germany's Vorpommern region, whose people seem generally similar to others of the Western German population, but are in fact shown to be somewhat different genetically (Poetsch et al., 2003). Given research findings regarding the high level of homogeneity of the human population in Central and Eastern Europe as a whole (from this point of view) (Malyarchuk \& Derenko, 2001; Malyarchuk et al., 2002, Kasperaviciūte, Kucinskas, \& Stoneking, 2004), the fact that there are differences in the above case would tend to attest to a different past when it comes to the settlement of Eastern as opposed to Western Germany. Further research will certainly be in a position to verify the preliminary conclusions, and the results may prove significant to the subject matter taken up here, as investigations into the process of eastward colonisation undertaken by Germans i.a. revolve around the phenomenon of the arriving colonists marrying local women. This circumstance also applied to the Mediaeval process of colonisation taking place in the Germania Slavica area (Piskorski, 2005; Lübke, 2014), as well as still-later migratory processes involving areas further east (Śladkowski, 1969). Researchers in this way emphasise how a shortage of womenfolk looks like an inherent feature of every one of history's colonisation episodes (Piskorski, 2005). Genetic research on the communities in areas of the wider world subject to European colonisation found just the same (Sykes, 2007; Quintana-Murci et al., 2010; Reich, 2019).

\footnotetext{
2 Comparative analysis involving autosomal DNA that was carried out by Krishna Veeramah's team revealed distances from the Lusatian Sorbs as follows: Czechs 0.8, Poles 1.1, Eastern Germans (Leipzig) 1.8, inhabitants of Bratislava (Slovakia) 1.9, Germans (in general) 2.6, and Dutch 3.0 (Veeramah et al., 2011).
}

The above-cited observations relating to mtDNA and autosomal DNA can also be extended to results concerning Y-chromosome polymorphism. Indeed, researchers analysing Central European migrations have found that male-line differences may prove more useful than the ones relating to mitochondrial DNA (Kasperaviciūte et al., 2004).

In that connection, analysis of Y-chromosome polymorphism in Germany indicates clear differences between that country's western and eastern parts, above all where Haplogroup R1a is concerned. In the west, in such cities as Mainz and Münster, the share accounted for by carriers may be of around 8\% (Kayser et al., 2005). The same is true in areas coming within the Germany of the Middle Ages that are today Belgian (Larmuseau et al., 2015) or Dutch (Altena et al. 2019), with R1a in those populations at a level of just $4 \%$ (Tab. 1). It is from these very regions (West Franconia, Westphalia, Flanders, Holland, Wallonia and Friesland) that most of the emigrants participating in colonisation to the east of Limes Sorabicus in the Middle Ages came (Rutkowski, 1953; Karszniewicz-Mazur, 1988; Kirsch, 2004).

However, work on Eastern Germany's regional centres of today - which lie to the east of the old Limes Sorabicus - shows that in most cases (Leipzig, Dresden, Halle and Rostock), carriers of Haplogroup R1a constitute around $30 \%$ of the population (Immel, Kleiber \& Klintschar, 2005; Kayser et al., 2005; Rodig, Grum \& Grimmecke, 2007; see Tab 1). A quite major departure from these results applies in the case of the supra-regional Berlin (R1a on 22.3\%) as well as the 50,000-inhabitant centre of local significance that is Greifswald (where the level is 19.2\%) (Kayser et al., 2005). While the former has long attracted migrants from various corners of Germany, the latter will only have represented much of an attraction for people in the immediate vicinity. On the other hand, in another Eastern German local community - of the (mostly already-Germanised) Lusatian Sorbs, the share taken by line R1a is as high as 65\% (Rębała et al., 2013). 
Table 1. Genetic structure (\%) in Poland, Lithuania, Germany, Belgium (Flemings) and The Netherlands by the most-numerous male lines (Y-chromosome polymorphism)

\begin{tabular}{|l|c|c|c|c|}
\hline \multicolumn{1}{|c|}{ City } & R1a & R1b & I & Other \\
\hline Lusatian Sorbs & 65.0 & 9.8 & 14.7 & 10.6 \\
Kraków & 64.0 & 8.0 & 15.0 & 13.0 \\
Lublin & 62.5 & 12.5 & 11.6 & 13.4 \\
Kashubians & 62.3 & 9.3 & 18.1 & 10.3 \\
Bydgoszcz & 55.6 & 14.8 & 18.3 & 11.3 \\
Lithuanians & 44.9 & 5.1 & 10.2 & 39.8 \\
Dresden & 32.6 & 31.5 & 18.0 & 18.0 \\
Rostock & 31.3 & 32.3 & 22.9 & 13.5 \\
Halle & 27.4 & 30.3 & 20.9 & 21.4 \\
Leipzig & 27.1 & 43.1 & 14.6 & 15.2 \\
Berlin & 22.3 & 23.3 & 32.0 & 22.4 \\
Magdeburg & 21.0 & 34.0 & 25.0 & 20.0 \\
Greifswald & 19.2 & 37.5 & 24.0 & 19.3 \\
Hamburg & 16.8 & 37.9 & 31.7 & 13.6 \\
Cologne & 15.6 & 41.7 & 19.8 & 22.9 \\
Mainz & 8.4 & 44.2 & 22.1 & 25.3 \\
Münster & 7.8 & 37.3 & 26.5 & 28.4 \\
Flemings & 4.2 & 62.9 & 20.0 & 13.0 \\
Dutch & 4.0 & 57.9 & 27.8 & 10.3 \\
\hline Sources: Kasperavis
\end{tabular}

Sources: Kasperaviciūte et al. 2004, Immel et al. 2005, Kayser et al. 2005, Rodig et al. 2007, Rębała et al. 2013, Larmuseau 2015 and Altena et al. 2019.

For such reasons, results for the cities of regional significance of 200$-500,000$ inhabitants (Leipzig, Dresden, Halle and Rostock) - which attract incoming migrants from all corners of their regions were viewed as more representative (better averaged) where the aim was to assess overall genetic differentiation of the population in areas to the east of the Elbe and Saale. And against that background it needs to be noted that the populations of the above cities differ little from one another when it comes to the shares of Haplogroup R1a carriers (in the $27-33 \%$ range).

An intermediate share in relation to most of the regional centres of Eastern and Western Germany is characteristic for Haplogroup R1a in Magdeburg (21.0\%), Hamburg (16.8\%) and Cologne (15.6\%). The first two cities located on the Elbe - on the Franconian side of the old Limes Sorabicus - may present the situation characteristic for a narrow transitional border zone (more on this below). In contrast, in the late 19th and early 20th centuries, Cologne and the adjacent cities of the Ruhr not included in the study were a target for an enhanced migratory inflow from the east (including from lands that were Polish). This inter alia ensures a still-elevated share of surnames of Polish origin in this part of Germany (Dräger \& Schmuck 2009; Kowalski \& Śleszyński, 2012).

In connection with the clear differences noted for shares of Haplogroup R1a carriers among the regional centres of Eastern Germany (R1a around 30\%) as opposed to typical regional centres of Western Germany (Münster and Mainz) plus Belgium and The Netherlands (R1a on 4-8\%), we may further note how a high share of carriers of Haplogroup 
R1a characterises neighbouring Slav peoples. It accounts for $57 \%$ of Poles, $53 \%$ of Belarusians, $47 \%$ of Russians, $45 \%$ of Slovaks, $44 \%$ of Ukrainians, $38 \%$ of Slovenes and $37 \%$ of Czechs (Kayser et al., 2005; Kushniarevich et al., 2013, 2015). A high (ca. 40\%) share of R1a in the male line also characterises the Balt peoples known to be closely-related to the Slavs (Kasperaviciūte et al., 2004).

At the same time, researchers emphasise that the presence of subclades M458 and Z280>M558 within this haplogroup can also be linked to the presence and migrations of Slav people (Kushniarevich et al., 2012; Mielnik-Sikorska et al., 2013; Underhill et al., 2014). This regularity is confirmed by work on the Lusatian Sorbs as the only surviving group of such people in Eastern Germany. Among those people, carriers of Haplogroup R1a take a share as high as $65 \%$, with a very clear dominance of subclade M458 (Rębała et al., 2013). This supports the contention that, also among the remaining Polabian Slavs (just as among the Slav peoples of nearby areas), there was a major role for carriers of Haplogroup R1a whose subclades are the ones present in Slavs above all (i.e. M458 and Z280). Their assimilation within new German communities would explain the major admixture of these genealogical lines among today's Germans from the east.

The team led by K. Rębała referred to the structure characterising male-line differentiation in selected regions of today's Poland and Germany in concluding that the results for a local community in Mecklenburg not defined in any further detail $(\mathrm{R} 1 \mathrm{a}=13.7 \%)$, along with results obtained by earlier groups (i.a. that of M. Kayser), point to a distinct $(\sim 20 \%)$ share of the descendants of Slavs in the development of certain of today's Eastern German regional communities (Rębała et al., 2013).

Against that background, the aim of the work presented here has been to verify such a hypothesis regarding a major role for descendants of the old Slavs and Balts in the formation of certain Eastern German regional communities.
With that aim in mind, it was decided to seek answers to questions as follows:

- Can information on migratory movements and ethnic phenomena ongoing in the area researchers call Germania Slavica or the Ostelbien confirm a major role for Slav people in the forming of new German regional communities?

- Did (Does) the old Limes Sorabicus - i.e. the border (or zone-like frontier) separating German people prior to their eastward colonisation (i.e. Saxons, Thuringians and Franks) from Slav people (Sorbs, Stodorans, Obotrites and Veleti) represent a relict border separating an originally-German community (with a low share of R1a) from a community that arose east of the Elbe and Saale as a result of the intermingling of migrants from the west with an autochthonous Slav population (in which the share of carriers of R1a was relatively high)?

\section{Research methodology}

The research work detailed here was pursued in line with two approaches. The first, traditional one concerned analysis of research results from the social sciences and the humanities as regards the ongoing assimilation of Slav and Balt peoples in Eastern German territories that are known as Germania Slavica in the context of the Mediaeval era, as well as the Ostelbien for the onset of the Modern era through to quite-recent times. The new approach in turn analyses of contemporary genetic-test results. While the traditional aspect focuses on what it has been possible to establish regarding assimilations of Slavs and Balts to the east of the old Limes Sorabicus, in the context of an eastward colonisation by Germans that apparently ran its course during the Middle Ages, the genetic aspect confines itself to Y-chromosome polymorphism, with use being made of results relating to today's Eastern German regional communities (from the teams of D.-U. Immel, M. Kayser and $H$. Rodig). This work was augmented by analysis of data available via the Family Tree DNA (hereinafter FTDNA) 
portal of the Texas-based firm Gene by Gene', in order to reconstruct the spatial differentiation characterising the shares taken by different male lines in the now-no-longer-existing eastern provinces of Germany.

The limiting of the research to differences in the male line was dictated by the availability of data. However, numerous studies of different populations and areas confining themselves to the analysis of Y-chromosome polymorphism show that such data can readily support conclusions as to the degree of relatedness of different populations, and the processes of migration ongoing between them (Kayser et al., 2005; Immel et al., 2006; Rębała et al., 2007; Balanovsky et al., 2008; Niederstätter et al., 2012; Kushniarevich, 2012; Karachanak et al., 2013; Mielnik-Sikorska et al., 2013; Rębała et al., 2013; Pliss et al., 2015; Neparáczki et al., 2019).

Data for the contemporary and historical Germanies were used to develop an isoline map. Given the characteristically major role for the male R1a line in the Slav populations, the focus was first and foremost on its variability in the populations under study. In the face of the low frequency of occurrence of this male-line haplogroup in the original West German population, it was believed that this would prove a very good indicator by which to define the Slav participation in the shaping of populations. In any case, it was not possible to find another Y-DNA haplogroup capable of serving as a marker by which to distinguish the original West Slavic and West German societies in the context of the analysis pursued. For, in the case of the abundant Haplogroup $\mathrm{R} 1 \mathrm{~b}$, it is possible to note clear differences in the shares among people playing their part in the eastward colonisation event (Flemings - 62.9\%, Dutch - 57.9\%, Mainz - 44.2\%, Münster - 37.3\%) (see Tab. 1). Following other researchers in assuming a major role for the Flemings, Dutch and Walloons in the process of eastward colonisation, it may be assumed that the effect of their mixing with local Slav people (R1b 10\%) in equal proportions would

\footnotetext{
3 www.familytreedna.com
}

go unobserved $[(62,9 \%+10 \%) / 2=36,5 \%$, so just like the values in Münster] in comparison with the Saxon population bordering directly with the tribes of Polabian Slavs along the Limes Sorabicus. It would also be hard to determine the share of emigrants on this basis, in particular cities or regions - given that same might have a prevalence of Flemish people, others Saxons.

For the above reason, R1a looked like the more-suitable marker, its share being similar in both groups (in the 4-8\% range), just as it is similar in the Western Slav populations present in isolation (with a 65\% level among the Lusatian Sorbs and 62\% among the Kashubians) or far from Germany (64 and $62 \%$ respectively in the Polish cities of Kraków and Lublin). In turn, a distinguishing marker in the case of the first Western German and Baltic communities (Eastern Prussians) is considered to be male-line N Y-DNA, which identifies the Balts (Kasperaviciūte et al., 2004), while not being present among the Western German peoples.

\section{The process of the Germanisation of Slavic and Baltic peoples}

The new German communities forming to the east of the Limes Sorabicus in the period of eastward colonisation (12th-14th-century) arose with the noticeable participation of local Slavs and Balts, who underwent rather rapid acculturation under the influence of the emigrants from west (Kirsch, 2004; Lübke, 2014). Equally, there were considerable areas in which emigrants hardly settled at all, in which the process of Germanisation of Slav and Balt peoples therefore lasted far longer. This was for example the case on Rugia Island (in the western part of Western Pomerania) - where a Slavic language persisted through to the early 15th century at least (Lübke, 2014). In the 19th century, Wincenty Pol noted that remnants of the first population of Rugia remained on the Mönchgut Peninsula, the people there being called Fisherfolk (Reboken) and differing in their costumes, and above all their way of speaking 
(which supported such words of Slavic origin as reba, żywot, ziemia, dziewka, perekop, piorun, and so on) (Pol, 1898). Grzegorz Smulski (1911) had similar observations regarding the people in question.

The Germanisation of the Slav population in the eastern part of Western Pomerania was also much more protracted. According to Prussian statistics, at the start of the 19th century there were 165,000 Protestant Kashubians and Slovincians (otherwise Wends or Wenden) living there, with these representing a quarter of the entire population of the Pomeranian province, as well as around two-thirds of the people living in the Regency of Köslin/ Koszalin (Hassel 1923) (Fig. 2). However, earlier remarks and observations suggest that Slav settlement extended further west as far as Dziwnów (the eastern edges of Wolin Island). Nevertheless, by the 18th century, the local people here too had Germanised, even though their origins were attested to by their customs, as well as a characteristic way of speaking German (Filip, 2012). By the 1930s, despite a considerable overall increase in population, Western Pomerania was home to just 5000 Kashubians, living around Bytów and Lębork (Skóra, 2004).

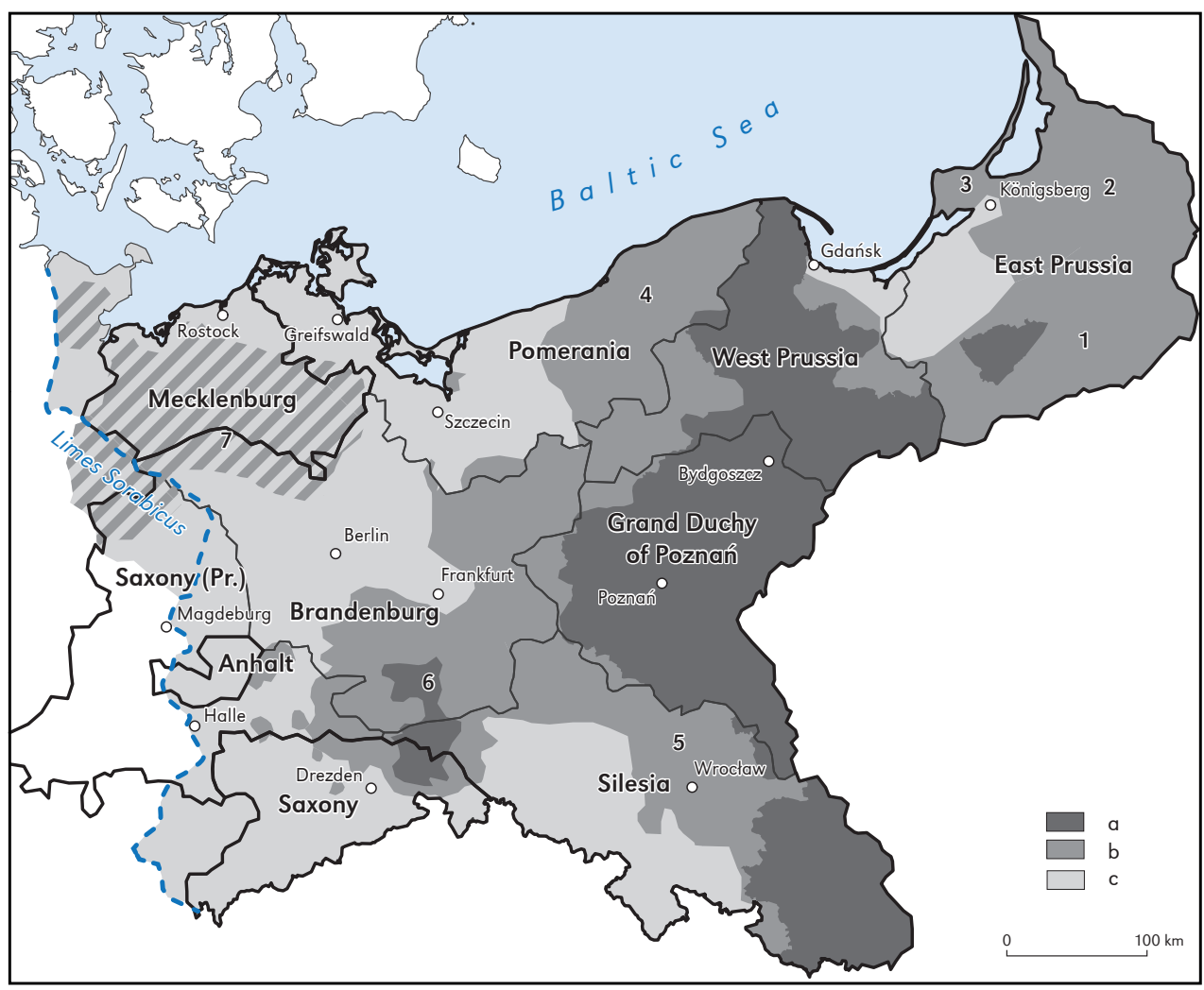

Figure 2. The process of Germanisation of the German East in the period between the 10th and 20th centuries, $a$ - areas with a prevalent Polish or Lusatian Sorb population at the beginning of the 20th century, $b$ - areas Germanised between the 16th and early 20th centuries, c - areas Germanised between the 10th and 16th centuries. Slavic and Balt peoples in the Eastern German region: 1 - Masurians, 2 - Prussian Lithuanians, 3 - Old Prussians, 4 - Kashubians/Slovincians, 5 - Polish Silesians, 6 - Lusatian Sorbs, 7 - Polabian Wends. Source: author's own elaboration on the basis of Putzger et al. (1893), Kaczmarczyk (1953), Šołta (1984), Wolski (1986) and Matulevičius (2019) 
Through to the 16 th or even early 17 th centuries, a Slavic language was also in use in the Mecklenburg and Brandenburg borderland area (longest of all near Grabow, Ludwigslust and Dömitz) (Putzger et al., 1893; Tetzner, 1902; Wolski,1986; North, 2015) (Fig. 2). An extension of this Slav area of settlement was neighbouring Wendland - located on the far side of the Elbe, in the eastern part of what is today Lower Saxony (near Lüneburg). Here a Slav language persisted through to the mid18th century, while local people maintained an ethnographic distinctiveness until the late 19th and early 20th centuries (Tetzner, 1902). Karol Arnošt Muka, who carried out relevant research at that time, noted that, notwithstanding Germanisation: "there remained in that land an old Slav national grouping with types and means of settlement, customs and habits unchanged through to this day in the character and outlook of the inhabitants" (Muka, 1905).

Retaining their separate identity and language through to the present day are a small (20-60,000-strong) group of Slav people living in the central part of Lusatia/ Lausitz, as now divided mainly between German Brandenburg and Saxony (Sachsen) (Szczepankiewicz-Battek, 2005; Dołowy-Rybińska, 2011). Even into the Modern era, the area settled by this group was in fact far larger, and also therefore encompassing the eastern part of the former province of Prussian Saxony or Preußisches Sachsen (Fig. 2). Despite centuries of assimilation, there were still around 230,000 people assigned to the Lusatian Sorb category as at the beginning of the 19th century (Hassel, 1923).

Looking rather similar was the process of Germanisation among the Polish-speaking inhabitants of Lower Silesia. The effect of the Mediaeval colonisation process was for German settlement to concentrate in the Sudety Mountains and their forelands (Cetwiński, 2001). But, despite the more-rapid Germanisation, even here the new community arose out of a mixing of Polish and German settlement - as research into the settlement processes taking place around the town of Nysa has made plain (Schich \& Stephan, 2015). Further to the north, above all in the part of Lower Silesia beyond the right bank of the Oder, the concentrations of Polish speakers remained in place for much longer (Fig. 2). Even at the end of the 18th centu$r y$, the Polish language was still dominant around (today's Polish) Oława, Syców and Namysłów, though by the early 20th century it had gone out of use almost entirely there (Kaczmarczyk, 1953; Kokot, 1974; Janczak \& Ładogórski, 1976).

The significance of the process of Germanisation of local people in shaping Eastern German regional communities is also confirmed by studies of the demographic history of East Prussia referred to in the Introduction. This region was inhabited, not only by Germans, but also by Prussians, Poles (Masurians and Varmians) and Lihuanians (Fig. 4). The Old Prussian language hung on in Natangia through to the end of the 16th century, and even to the early 18th in Sambia (Zabrocki, 1961). The Polish and Lithuanian languages persisted through to the 20th century (Srokowski, 1937). Research shows that, as of 1708, 33.8\% of the inhabitants of East Prussia were of (Old) Prussian ancestry, while 21.2\% were ethnically Lithuanian. Together that represented $55 \%$ of this region's inhabitants. The same research put the share of people who were of German origin at $24.6 \%$, leaving 18.8\% who were Polish (Masurian) (Kossert, 2004, Jurkat, 2005).

In the face of such statistics, it needs to be acknowledged that, as of 1910, 2/3 of the ancestors of German-speaking East Prussians $(80 \%$ of the population overall) were of Balt or Slav origin. Nonetheless, by the first half of the 20th century, both the Polish-and Lithuanian-speaking minorities had come to identify with the German community. Capable of attesting to this are the results of a plebiscite held in Masuria in which just 2\% came out in favour of Poland (Stawecki \& Wrzesiński, 1986); as well as the negative reactions of inhabitants of the Memel Territory (Klaipeda region) to incorporation into Lithuania (German parties standing for the Local 
Assembly garnered around $80 \%$ of all votes cast) (Gonschior, 2005), and the ultimate outmigration of these communities to Germany in the aftermath of World War II.

\section{The effect of Limes Sorabicus from the perspective of research into contemporary populations of Germany}

Cursory observation of the graded sequence characterising results between Flanders and The Netherlands at one end and the Kashubian and Lusatian areas on the other might suggest a smooth transition from a low share of representatives of the R1a male line in the west through to their dominance in the east resulting from free gene flow. This phenomenon does not of itself negate the hypothesis set at the outset, however its absence would represent a major argument serving to confirm it. It therefore seems necessary to follow the research cited in the Introduction in considering that Haplogroup R1a results for German regional centres east of the Elbe and Saale contrast very markedly with those for corresponding centres located in Western Germany. The "fault line" nature of the Limes Sorabicus zone gains confirmation on isoline maps presenting the shares of R1a carriers across Germany and beyond (Fig. 3). This map has been developed by building upon the aforementioned projects, and - thanks to generalisation of data gathered from a relatively small number of reference points (also with no account taken of the results for the small communities that Greifswald and the Lusatian Sorbs represent) - it conveys very effectively the overall trend present.

The map shows a denser packing of isolines for the share of R1a in the vicinity of the old Limes Sorabicus (three isolines between Hamburg and Rostock and only two in the more extensive western rest of Germany), suggesting major change across relatively small east-west distances, and hence the relative importance of the barrier present to the westward diffusion of R1a carriers. This therefore emphasises the significance of Limes Sorabicus to demographic processes across

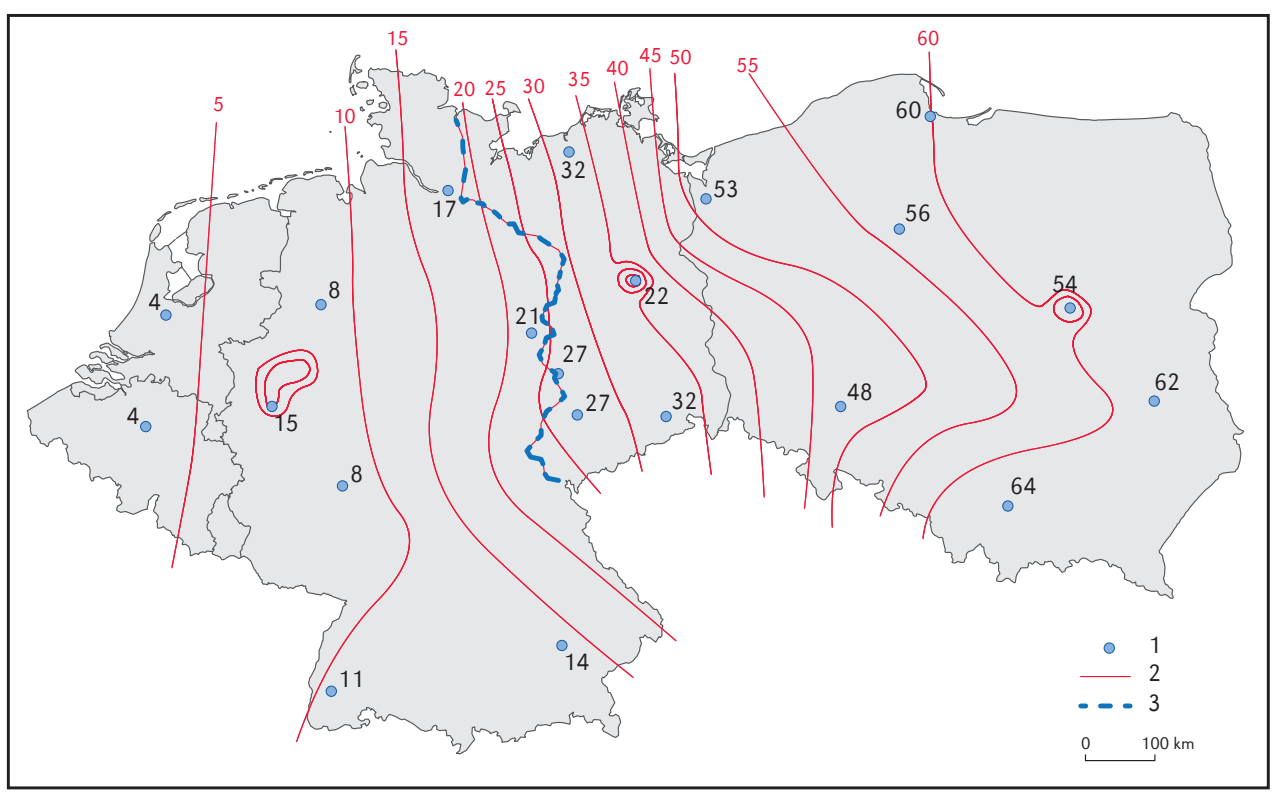

Figure 3. Map showing differences in the shares of male-line R1a across northern Central Europe. 1 - points of reference with values, 2 - isolines for the shares of R1a, 3 - Limes Sorabicus 
German areas, while confirming the distinct origins of part of the population on either side of the border. A second such zone - more intensive in character (four isolinies between Rostock and Szczecin and only two in the more extensive eastern rest of Poland) - is to be noted in today's Polish-German borderland (Fig. 3). However, this is the result of territorial changes and resettlements/expulsions of population arising out of the Second World War - as described in the aforementioned article (Kayser et al., 2005). Before WW2, the situation along the Oder-Neisse Line from the genetic point of view must have looked different (though this will be a matter for a further part of this study).

The situation described recalls the one to be observed in the north of European Russia. Genetic research has shown that ethnic Russians there were characterised by a high (ca. $43 \%$ ) level of participation of carriers of the Y-DNA N Haplogroup. Russians from the south differ in having just a $9 \%$ frequency of occurrence of this same haplogroup. Researchers felt this phenomenon could be linked with the assimilation (i.e. the Slavicisation) of Finno-Ugric peoples, among whom a characteristic feature is the high share of carriers of Haplogroup N (Balanovsky et al., 2008; Kushniarevich et al., 2015).

Thus, in both Germany and Russia, it is possible to observe the results of similar processes beginning in the Middle Ages: eastward German political, demographic and cultural expansion in lands settled by Slav tribes; and a similar kind of north-eastward Russian expansion in areas occupied by Finnish tribes.

\section{The impact of Limes Sorabicus prior to the territorial changes resulting from the Second World War}

It was decided to set the depiction of genetic differentiation in today's Germany against the one arising from history, and to do that use was made of the database accessible on the FTDNA genealogical portal. According to those researching issues of a genetic and genealogical nature, this is a well-developed set of data monitored by professional geneticists and genealogists that offers opportunities for various types of analysis to be carried out (Tetushkin, 2011).

Within the FTDNA database, a search was made for information on all people whose ancestors came from the former Eastern German provinces - of Brandenburg, Mecklenburg, Pomerania, Silesia, the Kingdom of Saxony, East Prussia, West Prussia and the Grand Duchy of Posen - and were born there pre-1914. For the purposes of comparison, the same principle was applied in the selection of data on people whose ancestors came from two originally-German areas just to the west of the old Limes Sorabicus - i.e. Franconia (the northern part of Bavaria) and Lower Saxony, as well as three regions traversed by the old Limes Sorabicus - which is to say Thuringia, Saxony (the Prussian province) and Schleswig-Holstein. For comparative purposes, data from the area of the pre-1914 Kingdom of Poland (so-called Russian Poland) was also collected.

The analysis presented here proceeded on the assumption that the ancestors of the people deciding upon this kind of test and posting their data on the FTDNA base were representative of the given regional community from the point of view of their genetic differentiation. It is hard to conceive - for example - that carriers of only certain of the Y-DNA haplotypes would be more willing to have themselves tested. Rather, it is expected that the choice took place more or less naturally in line with the activity of people alive today whose ancestors happened to be members of the community under study. We therefore avoid a situation whereby sample selection reflects decisions made by the researchers of a more or less arbitrary nature.

In calculating the genetic structure over larger areas (e.g. the whole of Germany east of the Elbe and Saale) account was taken of proportions that reflected the numbers of inhabitants in different provinces, with reference also made to relevant results from the 1910 Census. 
Table 2. Genetic and genealogical structure (\%) of selected regions of Germany pre-1918

\begin{tabular}{|c|c|c|c|c|c|c|c|c|c|c|c|c|c|c|c|c|c|c|c|c|c|c|c|c|}
\hline \multirow{2}{*}{ Region } & \multicolumn{2}{|c|}{ C } & & \multicolumn{2}{|c|}{ G } & \multicolumn{2}{|c|}{11} & \multicolumn{2}{|c|}{12} & \multicolumn{2}{|c|}{ J } & \multicolumn{2}{|c|}{$\mathrm{N}$} & \multicolumn{2}{|c|}{ Q } & \multicolumn{2}{|c|}{ R1a } & \multicolumn{2}{|c|}{ R1b } & \multicolumn{2}{|c|}{ T } & \multicolumn{2}{|c|}{ Overall } \\
\hline & $\mathrm{N}$ & $\%$ & N & $\%$ & $\mathrm{~N}$ & $\%$ & N & $\%$ & N & $\%$ & $\mathrm{~N}$ & $\%$ & $\mathrm{~N}$ & $\%$ & N & $\%$ & N & $\%$ & $\mathrm{~N}$ & $\%$ & $\mathrm{~N}$ & $\%$ & $\mathrm{~N}$ & $\%$ \\
\hline East Prussia & - & 0.0 & 2 & 2.2 & 2 & 2.2 & 13 & 14.1 & 4 & 4.3 & 4 & 4.3 & 19 & 20.7 & & 0 & 36 & 39.1 & 12 & 13.0 & & 0.0 & 92 & 100 \\
\hline West Prussia & - & 0.0 & 10 & 6.7 & 5 & 3.3 & 14 & 9.3 & 15 & 10.0 & 2 & 1.3 & 5 & 3.3 & 1 & 0.7 & 61 & 40.7 & 36 & 24.0 & 1 & 0.7 & 150 & 100 \\
\hline Pomerania & - & 0.0 & 3 & 3.1 & 2 & 2.1 & 15 & 15.6 & 5 & 5.2 & 3 & 3.1 & - & 0 & & 0 & 44 & 45.8 & 23 & 24.0 & 1 & 1.0 & 96 & 100 \\
\hline Poznań/Posen region & - & 0.0 & 11 & 5.8 & 4 & 2.1 & 20 & 10.6 & 15 & 7.9 & 15 & 7.9 & 2 & 1.1 & 6 & 3.2 & 79 & 41.8 & 37 & 19.6 & - & 0.0 & 189 & 100 \\
\hline Silesia & - & 0.0 & 8 & 8.7 & 7 & 7.6 & 8 & 8.7 & 1 & 1.1 & 6 & 6.5 & 3 & 3.3 & 2 & 2.2 & 41 & 44.6 & 14 & 15.2 & 2 & 2.2 & 92 & 100 \\
\hline Brandenburg & - & 0.0 & 5 & 5.1 & 5 & 5.1 & 15 & 15.2 & 6 & 6.1 & 4 & 4.0 & 4 & 4.0 & & 0 & 40 & 40.4 & 20 & 20.2 & - & 0.0 & 99 & 100 \\
\hline Mecklenburg & - & 0.0 & 3 & 3.6 & 4 & 4.8 & 20 & 24.1 & 3 & 3.6 & 2 & 2.4 & 1 & 1.2 & 1 & 1.2 & 23.5 & 28.3 & 25.5 & 30.7 & - & 0.0 & 83 & 100 \\
\hline Saxony & 1 & 1.0 & 12 & 11.7 & 9 & 8.7 & 8 & 7.8 & 6 & 5.8 & 4 & 3.9 & - & 0 & 1 & 1.0 & 26.5 & 25.7 & 34.5 & 33.5 & 2 & 1.0 & 103 & 100 \\
\hline Thuringia & - & 0.0 & 8 & 8.8 & 4 & 4.4 & 12 & 13.2 & 5 & 5.5 & 4 & 4.4 & 1 & 1.1 & & 0 & 22 & 24.2 & 34 & 37.4 & 1 & 1.1 & 91 & 100 \\
\hline Saxony (Prussian) & - & 0.0 & 7 & 6.5 & 7 & 6.5 & 15 & 14.0 & 6 & 5.6 & 8 & 7.5 & 1 & 0.9 & 1 & 0.9 & 18 & 16.8 & 44 & 41.1 & - & 0.0 & 107 & 100 \\
\hline Schleswig-Holstein & - & 0.0 & 6 & 4.4 & 5 & 3.7 & 31.5 & 23.2 & 17.5 & 12.9 & 7 & 5.1 & 2 & 1.5 & 2 & 1.5 & 19 & 14.0 & 43 & 31.6 & 3 & 2.2 & 136 & 100 \\
\hline Lower Saxony & - & 0.0 & 11 & 4.2 & 11 & 4.2 & 61 & 23.1 & 26 & 9.8 & 19 & 7.2 & 1 & 0.4 & 3 & 1.1 & 26 & 9.8 & 105 & 39.8 & 1 & 0.4 & 264 & 100 \\
\hline Franconia & - & 0.0 & 10 & 6.6 & 21 & 13.9 & 14.5 & 9.6 & 10.5 & 7.0 & 23 & 15.2 & - & 0 & & 0 & 16 & 10.6 & 53 & 35.1 & 3 & 2.0 & 151 & 100 \\
\hline Total & 1 & 0.1 & 96 & 5.8 & 86 & 5.2 & 247 & 14.9 & 120 & 7.3 & 101 & 6.1 & 39 & 2.4 & 17 & 1.0 & 449 & 27.2 & 465 & 28.1 & 13 & 0.8 & 1653 & 100 \\
\hline
\end{tabular}

Source: author's own elaboration on the basis of FTDNA data. 
The FTDNA database supplied information on the Y-DNA haplogroups of 1653 people from pre-1914 Germany, with adequate numbers of cases available for all of the regions under consideration (Table 2). The research revealed the presence of carriers of 9 main Y-DNA haplogroups present in Germany (Kayser et al., 2005), including Haplogroup C - which is currently a major rarity in Europe (Scozzari et al., 2012). In addition, data for 495 people for pre-1914 Russian Poland were obtained, grouped in five regions (Warsaw, Łódź, Kielce, Lublin, Białystok).

Sample size is similar to that obtained for Germany within the framework of traditional research into Y-chromosome polymorphism (e.g. Kayser et al., 2005). Also attesting to a clearly representative character is comparison with data obtained through standard scientific projects. Overall, data for the largest cities of Saxony (Dresden), Mecklenburg (Rostock) and Prussian Saxony (Magdeburg) - as the centres best representing the three regions - prove to be very similar to those obtained from the FTDNA (Tab. 3).

Further checking of the fit between data from the two sources was achieved using a chisquared test for the series (real data from the FTDNA and theoretical data from research into today's populations). The null hypothesis assumed that the distribution of variables in both data series was consistent. The level of significance was set at $p=0.05$. For the applied test statistic, $p=0.0516$ was obtained (chi-squared value 12.5, 6 df). The null hypoth- esis could not be rejected, although the test result is on the verge of achieving statistical significance. However, a major influence accounting for the minor discrepancies between the two series is exerted by the high share taken when the less-numerous haplogroups $(G, J$ and $E$ ) are lumped together in the FTDNA data for Saxony (Tab. 4).

In any case, an expectation that the datasets would prove identical would seem to be made highly unrealistic, given the stormy course of 20th-century events across Germany, and the demographic changes (including mass migrations) associated with them. The most important issue would seem to be that the difference observed make logical reference to real changes. Post-War there was an influx of German people from the east among which R1a was better-represented. This fact is discernible from even a cursory comparison of the two series of data - in the case of Prussian Saxony above all (Tab. 3). Such conclusions would only seem to confirm further the considerable value and truly representative nature of data obtained from the FTDNA - in fact in the case of all the provinces encompassed by the research (including those no longer in existence).

Overall, the data obtained from the FTDNA show how the German provinces east of the medieval Limes Sorabicus are characterised by structure of male lines distinct from the one known from more-westerly parts of Germany. This is particularly true given the high (38.3\%) share of male-line R1a in the

Table 3. Structure of (Y-DNA haplogroup) male lines (\%) in three regions of Germany. Comparison of the results of scientific projects with data from the FTDNA base

\begin{tabular}{|l|c|c|c|c|c|c|}
\hline \multirow{2}{*}{$\begin{array}{c}\text { Y-DNA } \\
\text { haplogroup }\end{array}$} & \multicolumn{2}{|c|}{ Mecklenburg } & \multicolumn{2}{c|}{$\begin{array}{c}\text { Saxony } \\
\text { (Prussian province) }\end{array}$} & \multicolumn{2}{c|}{$\begin{array}{c}\text { Saxony } \\
\text { (Kingdom) }\end{array}$} \\
\cline { 2 - 7 } & $\begin{array}{c}\text { Rostock } \\
\text { Kayser(2005) }\end{array}$ & $\begin{array}{c}\text { Mecklenburg } \\
\text { FTDNA }\end{array}$ & $\begin{array}{c}\text { Magdeburg } \\
\text { Kayser(2005) }\end{array}$ & $\begin{array}{c}\text { Prussian Saxony } \\
\text { FTDNA }\end{array}$ & $\begin{array}{c}\text { Dresden } \\
\text { Rodig (2007) }\end{array}$ & $\begin{array}{c}\text { Saxony } \\
\text { FTDNA }\end{array}$ \\
\hline R1a & 31.3 & 28.3 & 21.0 & 16.8 & 32.6 & 25.7 \\
R1b & 32.3 & 30.7 & 34.0 & 41.1 & 31.5 & 33.5 \\
I & 22.9 & 27.7 & 25.0 & 19.6 & 18.0 & 13.6 \\
\hline Other & 13.5 & 13.3 & 20.0 & 22.3 & 18.0 & 27.2 \\
\hline
\end{tabular}

Source: Immel et al. (2005), Kayser et al. (2005), Rodig et al. (2007), FTDNA. 
entire area, as well as the high (20.7\%) share of Haplogroup $\mathrm{N}$ noted among East Prussians (Tab. 2). The result is not much different where considerations are confined to ethnicallyGerman regions (and hence with the Posen/ Poznań region, so-called "Polish Corridor" and Upper Silesia excluded) (Tab. 5) ${ }^{4}$. Carriers of the R1a Haplogroup (with a decided prevalence of mutations M458 and Z280 ${ }^{5}$ ) represent $35.8 \%$ of those originating in this area (Fig. 2, Tab. 2).

Table 4. Part-values for the chi-squared test relating to three regions of Germany

\begin{tabular}{|l|c|c|c|c|}
\hline \multicolumn{1}{|c|}{ Region } & R1a & R1b & I & Other \\
\hline Saxony & 1.5 & 0.1 & 1.1 & 4.7 \\
Prussian Saxony & 0.8 & 1.5 & 1.2 & 0.3 \\
Mecklenburg & 0.3 & 0.1 & 1.0 & 0.0 \\
\hline
\end{tabular}

From the point of view of the share taken by Haplogroup R1a, Eastern Germans are seen to resemble today's Czechs (R1a on $37 \%$ ). They are separated by a distance similar to that applying to isolated Slav communities (R1a on 62-65\%), as opposed to today's Flemish, Dutch and Western Ger-

\footnotetext{
4 While R1a is present in $47.4 \%$ of male lines in Upper Silesia, the figure in Lower Silesia is only slightly lower at $42.6 \%$. In the part of Western Prussia incorporated into Poland after the First World War (socalled "Polish Corridor") the figure was $49.4 \%$, while in the part that stayed on in Germany and formed the Free City of Danzig it was 29.2\%.

5 Where data from the FTDNA relating to Mecklenburg are concerned for which subclades for haplogroup R1a could be identified (14 cases), there were 7 carriers with the M458 mutation, 5 with Z280, 1 with Z284 and 1 with Z93. At the same time, in neighbouring Lower Saxony (Niedersachsen) it was possible to note a prevalence of the subclades dominant in German populations (with Z284 in 4 cases, L664 and M458 also 4 and Z280 on 2). Also noteworthy is the major difference noted in the share of $\mathrm{R} 1 \mathrm{a}$ (with Mecklenburg's figure of $28.3 \%$ comparing with the $9.8 \%$ noted for Niedersachsen). This suggests that subclades characteristic for the Slav population present in the latter probably reflect the penetration of a small group of Slavs from the east (Lüneburg Wentland, in which a Slavic language persisted through to the 18th century - is located in the eastern part of Lower Saxony).
}

man people (R1a on 4-8\%). The similar shares of Haplogroup R1a carriers in the Czech and Eastern German population is noteworthy, and it may be supposed that both communities arose through the mixing of Western German and Western Slav settlement. This circumstance would have been favoured by a process of Slavicisation in the Czech lands (except the Sudetenland), in the face of Germanisation in Eastern Germany.

Using the data obtained from the FTDNA, it was also possible to develop an isoline map (Fig. 4), which was analogous to the one based on data from scientific projects (Fig. 3). In the case of data obtained from the FTDNA, the points of reference are the main urban centres in the regions under study, to which results obtained for those regions were ascribed. The depiction obtained is in general very similar to the map of today's Germany, confirming - only more clearly the existence of the aforementioned genetic "fault line" in a zone around the old Limes Sorabicus. As the map based on the FTDNA also takes account of data from what were previously Germany's eastern lands, two distinct parts of Germany can be noted quite clearly. On the one side, there is the greater part of the area of the Kingdom of Prussia with eastern Brandenburg, Western Pomerania, Silesia, Posen, Western and East Prussia located to the east of the $40 \%$ isoline - where variability in reported shares of R1a is limited. On the other side are western regions of Germany on German territory prior to the eastward colonisation, located to the west of the $15 \%$ isoline - where variability characterising shares of R1a is again limited. But between the 15 and $40 \%$ isolines there is a transition zone mainly concentrated to the east of the old Limes Sorabicus, in which there is very marked variability in the share of R1a along a line running east-west. In line with what is established in this way, today's Eastern Germany would largely fall within this transitional zone.

These results show how the no-longerextant German communities to the east of the Oder and Neisse had still higher shares of men of Slav or Balt origin among their 
Table 5. Male-line structure (\%) of Germans from the east (between the Elbe and the Neman) as set against the structure of today's ethnic populations

\begin{tabular}{|l|c|c|c|c|c|c|c|c|}
\hline $\begin{array}{c}\text { Y-DNA } \\
\text { haplogroup }\end{array}$ & $\begin{array}{c}\text { Lusatian } \\
\text { Sorbs } \\
\text { (Rębała } \\
\text { 2013) }\end{array}$ & $\begin{array}{c}\text { Poland } \\
\text { (Kayser } \\
\text { 2005) }\end{array}$ & $\begin{array}{c}\text { Germania } \\
\text { Slavica } \\
\text { (German } \\
\text { Prussians) }\end{array}$ & $\begin{array}{c}\text { Germania } \\
\text { Slavica } \\
\text { (whole) }\end{array}$ & $\begin{array}{c}\text { Czech } \\
\text { Republic } \\
\text { (Zastera } \\
\text { 2010) }\end{array}$ & $\begin{array}{c}\text { Germania } \\
\text { Slavica } \\
\text { (ethnically } \\
\text { German) }\end{array}$ & $\begin{array}{c}\text { West } \\
\text { Germans } \\
\text { (Kayser } \\
2005)\end{array}$ & $\begin{array}{c}\text { Flemings } \\
\text { (Larmuseau } \\
2015)\end{array}$ \\
\hline R1a & 65.0 & 57.5 & 40.5 & 38.3 & 36.9 & 35.8 & 12.7 & 4.2 \\
R1b & 9.8 & 12.5 & 19.7 & 21.7 & 24.8 & 23.6 & 42.4 & 62.9 \\
I1 & 9.8 & 17.3 & 14.0 & 11.7 & 8.3 & 12.6 & 24.1 & 20.0 \\
I2 & 4.9 & 5.7 & 5.1 & 9.1 & 5.6 & 2.7 & 0.0 \\
N & 0.0 & 3.7 & 6.1 & 3.8 & 2.4 & 4.3 & 2.7 & 13.0 \\
\hline Other & 10.6 & 10.4 & 14.0 & 19.4 & 18.5 & 18.0 & 18.1 & 13.0 \\
\hline
\end{tabular}

Source: author's own elaboration based on Rębała et al. (2013), Kayser et al. (2005), Larmuseau et al. (2015), Zastera et al. (2010) and the FTDNA database.

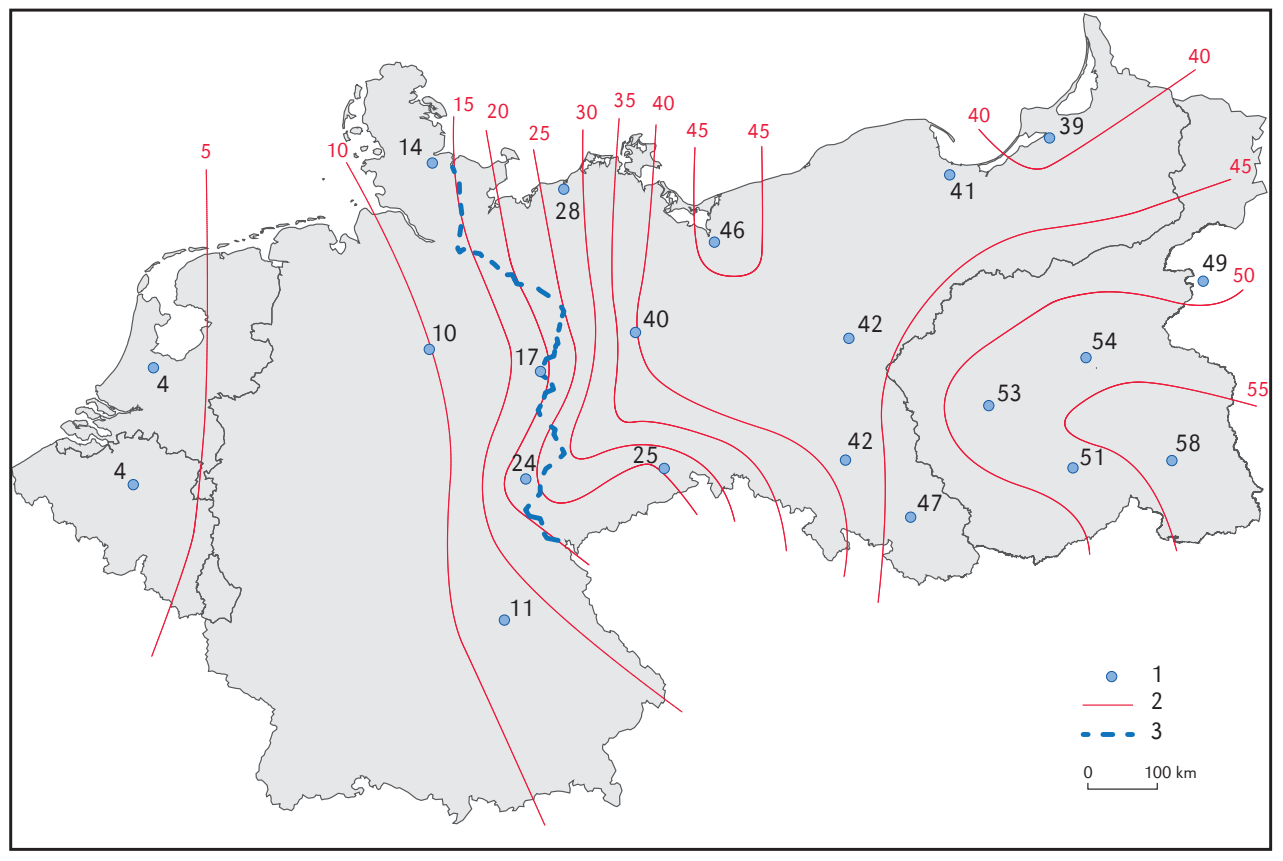

Figure 4. Map showing differences in male-line R1a shares for the population of northern Central Europe before 1914. 1 - reference points with values, 2 - isolines for the shares of R1a, 3 - Limes Sorabicus

forebears. These data could also reveal that a genetic "fault line" between the population of Germans from the east and that of Poland was small, even as there was a distinct feature of this kind between the two parts of Germany. This situation only changed with border changes and forced movement of populations resulting from the Second World War. The marked difference between Poland and Germany to be noted today is a consequence of those changes, as was emphasised in the work by M. Kayser's team (Kayser et al., 2005). 
However, it is still possible to discern a distinct genetic "fault line" relating to the shares accounted for by R1a along the old Limes Sorabicus running between eastern Germany (the old Slavia Germanica and Ostelbien) and that country's western part. This would emphasise the ongoing significance of the Limes Sorabicus zone as a boundary separating German communities that differ markedly in terms of their ancestral origins.

Bearing in mind these arguments, the similar shares of ancestors of Slav origin in different German communities on a regional or local level could be seen as a function of the proportion of the R1a line in the male population (other than in East Prussia, where the situation is complicated by a settlement of Balts). Assuming that the original Slav population had a male-line share at the level of $65 \%$ (as among today's Lusatian Sorbs), while the participants in the eastward colonisation were mainly on or around the 6\% level (that being the mean among today's Flemings, Dutch, Rhinelanders and Westphalians), a conclusion - if simplified - would be that, in the Ostelbien area (away from East Prussia), 6\% R1a denotes no Slav progenitors at all, while $65 \%$ means that $100 \%$ of the ancestors were Slav. That leaves a level of $35.5 \%$ R1a denoting $50 \%$ of the ancestors in a given population being of each origin. While obviously only applying where Western German settlement intermingled with that of the Western Slavs, this regularity could be described using the equation:

$$
f\left(x_{1}, \ldots, x_{k}\right) \downarrow=100 / 59 x_{(1 \ldots k)}-600 / 59
$$

where:

$x_{1}$ - is the share taken by R1a among - Western

German settlers (6\%), and

$x_{k}-$ is the share taken by R1a among Western Slavs (65\%).

Assuming this dependent relationship correct, the share of ancestors of Slav origin in the population of eastern Germany would be as shown in Tables 6 and 7 .

It is possible to note significant differences between the old Eastern German regions.
Bearing in mind the distinct natures of the former German states, it would be the Eastern German Prussians seen as having the fewest ancestors of German origin (41.7\%). These are then the population prevailing in Brandenburg, Lower Silesia, Pomerania, East Prussia, Prussian Saxony and West Prussia excluding the Polish "Corridor".

Table 6. Estimated shares (\%) of male-line ancestors of Slav origin within the population of today's Eastern German cities

\begin{tabular}{|l|c|c|}
\hline \multicolumn{1}{|c|}{ City } & R1a & Slav ancestors \\
\hline Dresden & 32.6 & 45.1 \\
Rostock & 31.3 & 42.9 \\
Halle & 27.4 & 36.3 \\
Leipzig & 27.1 & 35.8 \\
Berlin & 22.3 & 27.6 \\
Magdeburg & 21.0 & 25.4 \\
Greifswald & 19.2 & 22.4 \\
Hamburg & 16.8 & 18.3 \\
\hline
\end{tabular}

Table 7. Estimated shares (\%) of male-line ancestors of Slav origin within the population of the old (pre-1914) Eastern German regions

\begin{tabular}{|l|c|c|}
\hline \multicolumn{1}{|c|}{ Region } & R1a & $\begin{array}{c}\text { Slav } \\
\text { ancestors }\end{array}$ \\
\hline Pomerania & 45.8 & 67.5 \\
Lower Silesia & 42.6 & 62.0 \\
Brandenburg & 40.4 & 58.3 \\
Mecklenburg & 28.3 & 37.8 \\
Saxony & 25.7 & 33.4 \\
Thuringia & 24.2 & 30.8 \\
Prussian Saxony & 16.8 & 18.3 \\
Ethnically-German & 35.8 & 50.5 \\
Ostelbien (Prussia, Saxony & & \\
and Mecklenburg) & 40.4 & 58.3 \\
Prussia within the & & \\
ethnically-German & 10.6 & 7.8 \\
Ostelbien & 9.8 & 6.4 \\
Franconia & & \\
Lower Saxony & & \\
\hline
\end{tabular}

A rather higher share of male ancestors of German origin is implied by results 
obtained for Mecklenburg (62.2\%) and Saxony $(66.6 \%)^{6}$. However, in both cases, the share accounted for by the R1a Haplogroup is considerable (at 26-28\%) - sufficient to sustain a presumption that Slavs may have constituted at least $1 / 3$ of the male ancestors of local people. This actually exceeds the values present in certain of today's Balkan Slav nations, for example among Bulgarians (R1a $=17 \%)$ or Serbs $(\mathrm{R} 1 \mathrm{a}=18 \%)$. The latter nations arose in the early Middle Ages as a result of the mixing of Slavic tribes from the north with the local Balkan people (mainly Romanized Thracians and Illyrians) having a small share of R1a carriers (Skowronek, Tanty, \& Wasilewski, 1988; Kushniarevich et al., 2015; Kowalski, 2019c).

In East Prussia, what is visible alongside the dominant R1a component is a high (20.7\%) share of carriers of Haplogroup N (Tab. 2). This may attest to a considerable number of ancestors of Balt origin (Prussians, Lithuanians or Curonians), given the fact that the people living in the relevant areas today are characterised by a major presence, not only of Haplogroup R1a (at a level of some $40 \%$ ), but also of $N$ (whose share reaches 36.7\% among Lithuanians and 39.9\% among Latvians) (Kasperaviciūte et al., 2004). There is thus a basis for claiming that just over $50 \%$ of the male-line ancestors of the East Prussians were Balts. That figure also corresponds with the 55\% established by way of traditional research methods (Kossert, 2004; Jurkat, 2005).

Given this presence of a Balt population, Table 7 does not take East Prussia into account. Also for the same reason no consideration was given to ancestors of Balt origin anywhere in the Ostelbien. According to the calculations of traditional historical demography, the Balts and the Slavs in East Prussia

6 Where we consider Saxony (in the sense of the former Kingdom) together with the adjacent area of eastern Thuringia (the part to the east of the Saale), we in this way recreate what was once southern Polabia. Given that R1a has a $28 \%$ share there, this means that ancestry of Slav origin would be on the same level as in Mecklenburg (37.8\%). together account for around $74 \%$ of all ancestors (Kossert, 2004; Jurkat, 2005), with this therefore resulting in a raising of their combined share across the ethnically-German Ostelbien (to around 53\%) and throughout the Prussian part thereof (to around 61\%). It can be accepted on that basis that for Germany within its 1937 borders as a whole, Slavs and Balts together might have accounted for around $20 \%$ of all male forebears.

The results obtained are worth comparing with those from M. Kayser's team, which are referred to at regular intervals throughout this study. A synthetic depiction achieved by the authors' application of statistical analysis is as presented in the Figure 5. This shows the distances between different German communities - and Polish cities - studied, in relation to Y-chromosome polymorphism. What can be seen very clearly here are the intermediate positions of the Eastern German cities between the localities in Poland on the one hand and the western part of Germany on the other. The effect is seen particularly clearly where we confine ourselves to typical centres in Eastern Germany (Leipzig and Rostock), as well as the western part of the country (Münster and Mainz). Rostock shows particular proximity to Polish cities, though it remains slightly closer to Münster or Mainz. When this is set against the results of the author's research, the inhabitants of Rostock are seen to have had slightly more male progenitors of German origin (57.1\%) as opposed to Slav. In this context, the present of "empty space" between the Eastern German and Polish cities is understood readily enough, as it may be anticipated that this was filled by German communities now no longer in existence, but present through to the time of World War 2 in regions located to the east of the Oder and Neisse. Results of the present analysis in turn allow it to be presumed that the distance separating them from Polish communities would be smaller than the one separating them from typical communities of the western part of Germany.

Reference also needs to be made to the work by K. Rębała's team, which held that 


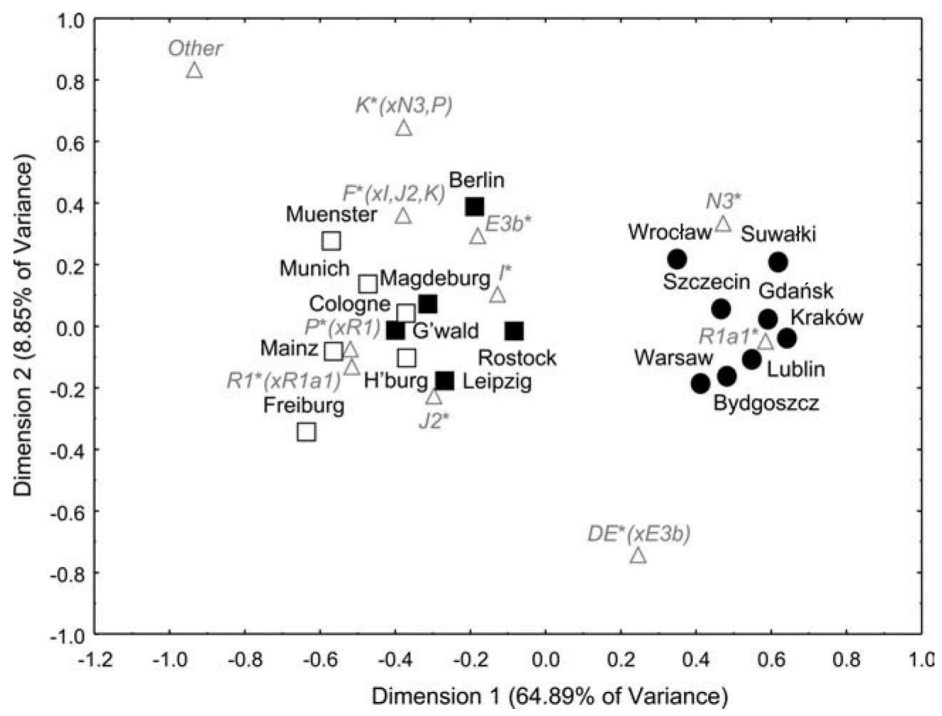

Figure 5. Correspondence analysis. Two-dimensional plot of the distribution of populations according to their Y-DNA haplogroup frequencies in correspondence with a plot of the haplogroups in the same graphical representation. Filled circles indicate Polish populations; filled squares indicate Eastern German populations and empty squares indicate Western German populations

Source: Kayser et al. (2005).

ancestors of Slav origin represented around $20 \%$ of all the male forebears of today's Eastern German communities. This is a value departing markedly from what was found in the present study (in which the share of male ancestors of Slav origin is presented by reference to data for contemporary centres of regional significance - across a range from $35.8 \%$ (in Leipzig) to $42.9 \%$ (Rostock) as well as - on the basis of FTDNA data - between 33.4\% (in Saxony) and 37.8\% (in Mecklenburg). However, as estimates from Rębała et al. took all the results of M. Kayser's team into account, that also denotes localities we view as not especially representative of the Slavia Germanica/ Ostelbien area, i.e. the small town of Greifswald, the out-of-area Magdeburg, and the capital city Berlin, which is of obviously German-wide significance. The estimates in question also drew on the Rębała team's own results concerning a not-more-precisely-defined local community in Mecklenburg, in which the share of carriers of Haplogroup R1a (at 13.7\%) was far lower than in the centres of regional significance we see as more representative.

\section{Conclusions}

Historical sources confirm how, between the 12th and 14th centuries, the Germania Slavica area saw many representatives of native (Slav and Balt) communities joined the German settlers from the west, creating new regional groupings of a German character. Nevertheless, large communities of the native peoples remained in existence in their vicinity.

Successive centuries all the way through to 1945 then witnessed further-ongoing integration between the two types of community, albeit on the basis of Germanisation of both language and culture. While some Slav and Balt groupings underwent assimilation within a German environment very early on (as on Rugia Island), others (like the Lüneburg Wends and Prussian Sambians) only did so somewhat later, while still-others (like the Masurians, Slovincians and Prussian Lithuanians) only did so during the lifetimes 
of still-living witnesses. Indeed, some of these communities remain in existence, if much reduced in terms of both numbers and areas occupied. Some (like the Lusation Sorbs) are today at risk of total acculturation, while others (most often located beyond today's borders of Germany, in the manner of the Upper Silesians) continue to reinforce German society as they tend to emigrate there.

Ideas regarding the course and scale of the above processes would seem to gain a great deal of support from genetic analyses, whether it be the ones pursued earlier by several different research teams (under Kayser, Immel, Rodig and Rębała), or those carried out for the needs of the present study in relation to Y-chromosome polymorphism among pre-1914 Eastern German regions.

The existence of a distinct genetic "fault line" in the zone of the medieval Limes Sorabicus (associated with differences in shares of male-line R1a on one side or the other) is suggestive of a major role for the descendants of Slavs and Balts in the development of the Eastern German regional groupings. There is therefore confirmation of the status of Limes Sorabicus as a barrier of significance in limiting migrations of people, and hence also of their genes.

High shares of R1a in ethnically-German populations extend towards the west to the zone formed by the Limes Sorabicus - thus to the former western border of Slavic settlement. This would seem to reflect the presence of Slavs in these areas in the Middle Ages, as well as a role for those local Slavs in the development of new regional German communities of the east. In Mecklenburg and Saxony, male lines deriving from Slav peoples came to be slightly dominated by those of incomers from the west - ensuring that this area mostly forms a transition zone. Equally, in Brandenburg, Pomerania, Lower Silesia and East Prussia, male lines having their origins among Slav and Balt peoples are (or were) the ones that prevail.

These observations do much to augment conclusions drawn by analyzing the processes via which local Slav populations underwent assimilation from Mediaeval times onwards. In areas receiving many emigrants from the west, with the result that ethnicallyGerman communities arose in the context of the colonisation process, local populations today have relatively limited shares of maleline Haplogroup R1a - just as work by M. Kayser's team revealed for Greifswald (R1a $19.2 \%)$, and as K. Rębała's group reported for an undefined population in Mecklenburg (among which R1a was at 13.7\%).

Equally, there are areas in which Slav and Balt communities continued to function for longer, and were only Germanised far later, under a cultural impact exerted by Germanspeaking neighbours, as well as institutions of the German state. There, local populations feature the high shares of male-line R1a reported by K. Rębała for the Lusatian Sorbs $(\mathrm{R} 1 \mathrm{a}=65.0 \%)$ and Kashubians (62.3\%), whose countrymen in neighboring areas were Germanized in the past. For this reason, regions of Germany to the east of the old Limes Sorabicus most probably have (or had) a checkerboard-like differentiation as regards shares of R1a in their populations, with local communities whose origins ensure(d) low or high figures for this haplogroup.

These values become (became) averaged only where the scale of whole Eastern German regions is addressed (with the figure being around 30\% between the Elbe and the Oder, and in the $40-45 \%$ range to the east of the latter river). This is what is shown by an analysis of results from the team comprising H. Rodig, M. Kayser and D.-U. Immel - in the case of centres of regional importance (i.e. Dresden, Halle, Rostock and Leipzig), as well as by reference to FTDNA data for formerly-German provinces. A high share for the R1a male line in the populations of Mecklenburg, Saxony, Brandenburg, Pomerania, Lower Silesia and East Prussia would thus be seen as the effect of two processes above all: an absorption of a small Slav and Balt population by settlers from the west as they colonised between the 12th and 14th centuries, and a later Germanisation of Slav and Balt communities that had 
survived the original period of eastward colonisation.

At the same time, such conclusions relegate to the realm of the absurd various racerelated theories from the past (though occasionally lingering through to the present day), which sought to demonstrate distinctiveness of origin of German and Slav nations, in the broader context of assertions with regard to racial or cultural superiority one or the other. For it emerges that the German population of the eastern core of the Prussian State (so without Rhineland and Westphalia) - as the leading centre of German political life in the 19th century - has an ancestral origin very similar to that of Czechia's Slav population. Through to 1945, this was also closer in terms of ancestral origin to the population of Poland than to that of Western Germany, also being separated from the latter by a far moredistinct genetic "fault line" given differences in the share taken by the R1a haplogroup.

The considerable role Slavs and Balts played in the formation of new German societies is also suggested by the aforementioned analysis of atDNA and mtDNA differentiation. Hence the main postulate arising from this analysis - that more-comprehensive genetic study needs to be engaged in to compare today's Eastern German regional populations with German and Slav populations, in regard to differences involving, not only Y-DNA, but also mtDNA and autosomal DNA. This is above all important on account of the autochthonous female (mtDNA) line, which may (as in other colonised areas) prove even more abundant than the autochthonous male lines, in this way revealing a yet-larger role for ancestors of Slav or Balt origin in the development of German regional groupings in the East.

\section{Editors' note:}

Unless otherwise stated, the sources of tables and figures are the authors', on the basis of their own research.

\section{References}

Altena, E., Smeding, R., van der Gaag, K.J., Larmuseau, M.H., Decorte, R., Lao, O., Kayser, M., Kraaijenbrink, T., de Knijff, P. (2019). The Dutch Y-chromosomal landscape. European Journal of Human Genetics, 28, 287-299. https://doi.org/10.1038/s41431-019-0496-0

Bański, J. (2010). Granica w badaniach geograficznych - definicja i próby klasyfikacji. Przegląd Geograficzny, 82(4), 489-508.

Berger, D. (1999). Geographische Namen in Deutschland. Mannheim: Duden.

Balanovsky, O., Rootsi, S., Pshenichnov, A., Kivisild, T., Churnosov, M., Evseeva, I., Pocheshkhova, E., Boldyreva, M., Yankovsky, N., Balanovska, E., Villems, R. (2008). Two sources of the Russian patrilineal heritage in their Eurasian context. The American Journal of Human Genetics, 82, 236-250. https://doi.org/10.1016/j.ajhg.2007.09.019

Cetwiński, M. (2001). Ślq̨ski tygiel: studia z dziejów polskiego średniowiecza. Częstochowa: Wydawnictwo Wyższej Szkoły Pedagogicznej w Częstochowie.

Gonschior, A. (2005). Wahlen in der Weimarer Republik. Retrieved from http://www.gonschior.de/weimar/Memelgebiet/Uebersicht_LTW.html [5 May 2020].

Dołowy-Rybińska, N. (2011). Języki i kultury mniejszościowe w Europie. Bretończycy, Łużyczanie, Kaszubi. Warszawa: Wydawnictwa Uniwersytetu Warszawskiego.

Dräger, K., Schmuck, M. (2009). The German surname atlas project - Computer-based surname Geography. In W. Ahrens, Sh. Embleton, A. Lapierre, G. Smith, M. Figueredo, (Eds.), Proceedings of the 23rd 
International Congress of Onomastic Sciences (pp. 319-336). Toronto: York University. Retrieved from https://yorkspace.library.yorku.ca/xmlui/bitstream/handle/10315/3961/icos23_319.pdf [5 May 2020].

Eddie, S.M. (2008). Landownership in Eastern Germany before the Great War: A quantitative analysis. Oxford - New York: Oxford University Press.

Engelmann, B. (2016). Co jest pruskie. In H.-J. Bomelburg, A. Lawaty (Eds.), Prusy - mity i rzeczywistość (pp. 470-478). Poznań: Nauka i Innowacje.

Family Tree DNA. Retrieved from www.familytreedna.com [5 May 2020].

Filip, M. (2012). Od Kaszubów do Niemców: Tożsamość Słowińców z perspektywy antropologii historii. Poznań: Nauka i Innowacje.

Granice Polski jako zasoby - pomiędzy dziedzictwem a produktem turystycznym, Retrieved from https://www.igipz.pan.pl/project_en/events/3_6953.html [5 May 2020].

Handschuh, L., Stolarek, I., Juras, A., Zeńczak, M., Marcinkowska-Swojak, M., Myszka, A., ... Różański, A. (2016). W poszukiwaniu Piastów. Opolskie Studia Administracyjno-Prawne, 14, 4(2), 63-77.

Hardt, M. (1999). Das slawische Dorf und seine kolonisationszeitliche Umformung nach schriftlichen und historisch-geographischen Quellen. Siedlungsforschung. Archäologie - Geschichte - Geographie, 17, 269-291.

Hartshorne, R. (1933). Geographic and political boundaries in Upper Silesia. Annals of the Association of American Geographers, 23(4), 195-228.

Hassel, J.G.H. (1823). Statistischer Umriss der Sämmtlichen Europäischen und der Vornhemsten Aufseuropäischen Staaten. 1, Weimar: Geographischen Institut.

Hawes, J. (2018). The shortest history of Germany. London: Old Street Publishing.

Immel, U.-D., Kleiber, M., Klintschar, M. (2005). Y chromosome polymorphisms and haplotypes in South Saxony-Anhalt (Germany). Forensic Science International, 155, 211-215.

https://doi.org/10.1016/j.forsciint.2005.01.004

Immel, U.-D., Krawczak, M., Udolph, J., Richter, A., Rodig, H., Kleiber, M., Klintschar, M. (2006). Y-chromosomal STR haplotype analysis reveals surname-associated strata in the East-German population. European Journal of Human Genetics, 14, 577-582. https://doi.org/10.1038/sj.ejhg.5201572

Ingrao, Ch.W., Szabo, F.A.J. (Eds.). (2008). The Germans and the East. West Lafayette: Purdue University Press. https://doi.org/10.2307/j.ctt6wq5f2

Janczak, J., Ładogórski, T. (Eds.) (1976). Śląsk w końcu XVIII wieku, 1(2), Atlas Historyczny Polski. Mapy XVIII wieku, 1. Wrocław: Ossolineum.

Jiménez, F. (2015). So sieht es in der Psyche von Ossi und Wessi aus. Die Welt. Retrieved from https://www.welt.de/gesundheit/psychologie/article147131006/So-sieht-es-in-der-Psyche-von-Ossiund-Wessi-aus.html [5 May 2020].

Juras, A. (2012). Etnogeneza Słowian w świetle badań kopalnego DNA. (Ph.D. thesis). Poznań: Uniwersytet im. Adama Mickiewicza w Poznaniu. Retrieved from https://repozytorium.amu.edu.pl/handle/10593/2702 [5 May 2020].

Jurkat, K.-P. (2005). Neue Beiträge zur Baltistik. Bergisch Gladbach: R \& R Printservice. Retrieved from http://prussia.online/books/neue-beitraege-zur-baltistik

Kaczmarczyk, Z. (1953). Rozprzestrzenienie się narodowości polskiej nad Odrą i Bałtykiem w późnym feudalizmie. Przeglad Zachodni, 9, 9-30.

Kałuski, S. (2017). Blizny historii. Geografia granic politycznych współczesnego świata. Warszawa: Wydawnictwo Akademickie Dialog.

Karachanak, S., Grugni, V., Fornarino, S., Nesheva, D., Al-Zahery, N., Battaglia, V., Carossa, V., Yordanov, Y., Torroni, A., Galabov, A.S., Toncheva, D., Semino, O. (2013). Y-chromosome diversity in modern Bulgarians: New clues about their ancestry. PLOS One, 8(3): e56779. https://doi.org/10.1371/journal.pone.

Karszniewicz-Mazur, A. (1988). Zapożyczenia leksykalne ze źródła niemieckiego we współczesnej polszczyźnie. Wrocław: Wydawnictwo Uniwersytetu Wrocławskiego. 
Kasperaviciūte, D., Kucinskas, V., Stoneking, M. (2004). Y Chromosome and Mitochondrial DNA Variation in Lithuanians. Annals of Human Genetics, 68(5), 438-452. https://doi.org/10.1046/j.1529-8817.2003.00119.x

Kayser, M., Lao, O., Anslinger, K., Augustin, Ch., Bargel, G., Edelmann, J., ... Hohoff, C. (2005). Significant genetic differentiation between Poland and Germany follows present-day political borders, as revealed by Y-chromosome analysis. Human Genetics, 117, 428-443.

https://doi.org/10.1007/s00439-005-1333-9

Kleiner Atlas der Siedlungsnamen Deutschlands, Retrieved from http://deutschlandkarten.nationalatlas.de/ [5 May 2020].

Kirsch, K. (2004). Slawen und Deutsche in der Uckermark: vergleichende Untersuchungen zur Siedlungsentwicklung vom 11. bis zum 14. Jahrhundert. Stuttgart: Franz Steiner Verlag.

Kokot, J. (1973). Problemy narodowościowe na Ślasku od X do XX wieku. Opole: Wydawnictwo Instytutu Śląskiego w Opolu.

Kolosov, V., Więckowski, M. (2018). Border changes in Central and Eastern Europe: An introduction. Geographia Polonica, 91(1), 5-16. https://doi.org/10.7163/GPol.0106

Kortus, B. (2004). Rola geografii w polskiej myśli zachodniej XX wieku. Przegląd Zachodni, 60(2), 105-130.

Kossert, A. (2004). Mazury. Zapomniane południe Prus Wschodnich. Warszawa: Scholar.

Kowalski, M., Śleszyński, P. (2012). The migration of Poles to Germany in the context of the frequency of the most common Polish surnames. Przeglad Zachodni, Special Issue, 119-135.

Kowalski, M. (2019a). Generational cycles and changes in time and space. Geographia Polonica, 92(3), 253-273. https://doi.org/10.7163/GPol.0148

Kowalski, M. (2019b). Spatial differences in voting behaviour among the inhabitants of rural areas in Eastern Europe. In J. Bański (Ed.), Three decades of transformation in the East-Central European countryside (pp. 143-163), Springer, Cham. https://doi.org/10.1007/978-3-030-21237-7_7

Kowalski, M. (2019c). Geografia średniowiecznej Słowiańszczyzny. Kultura Słowian. Rocznik Komisji Kultury Stowian PAU, 15, 15-64.

Krawczak, M., Lu, T.T., Willuweit, S. and Roewer, L. (2008). Genetic diversity in the German population. In eLS. https://doi.org/10.1002/9780470015902.a0020801

Krūmiña, A., Pliss, L., Zarina, G., Puzuka, A., Zarina, A., Lāce, B., Elferts, D., Khrunin, A., Limborska, S., Klovin,š, J., Gailìte Piekuse, L. (2018). Population genetics of Latvians in the context of admixture between North-Eastern European ethnic groups. Proceedings of The Latvian Academy of Sciences. Section B, 72, 3(714), 131-151. https://doi.org/10.2478/prolas-2018-0025

Kruse, W. (1929). Die Deutschen und ihre Nachbarvölker. Neue Grundlegung der Anthropologie, Rassen-, Völker-, Stammeskunde und Konstitutionslehre nebst Ausführungen zur deutschen Rassenhygiene. Leipzig: Thieme.

Kushniarevich, A.I., Sivitskaya, L.N., Bogacheva, A.V., Kotova, S.A., Tsybovski, I., S., Davydenko, O.G. (2012). The Y chromosome R1A1A7 (M458) haplogroup of modern Belarusians and migrations of ancestors of Slavs on Belarus' territory. Russian Journal of Genetics: Applied Research, 2(2), 114-121. https://doi.org/10.1134/S2079059712020062

Kushniarevich, A., Sivitskaya, L., Danilenko, N., Novogrodskii, T., Tsybovsky, I., Kiseleva, H., ... Bahmanimehr, A. (2013). Uniparental genetic heritage of Belarusians: Encounter of rare Middle Eastern matrilineages with a Central European mitochondrial DNA pool. PLOS One, 8(6): e66499. https://doi.org/10.1371/journal.pone.0066499

Kushniarevich, A., Utevska, O., Chuhryaeva, M., Agdzhoyan, A., Dibirova, K., Uktveryte, I., ... Pshenichnov, A.(2015). Genetic heritage of the Balto-Slavic speaking populations: A synthesis of autosomal, mitochondrial and Y-Chromosomal data. PLOS One, 10(9): e0135820.

https://doi.org/10.1371/journal.pone.0135820 
Leciejewicz, L. (1989). Stowianie zachodni. Z dziejów tworzenia się średniowiecznej Europy. Wrocław: Ossolineum.

Larmuseau, M.H.D., Boon, N., Vanderheyden, N., Van Geystelen, A., Larmuseau, H.F.M., Matthys, K., De Clercq, W., Decorte, R. (2015). High Y-chromosomal diversity and low relatedness between paternal lineages on a communal scale in the Western European Low Countries during the surname establishment. Heredity, 115, 3-12. https://doi.org/10.1038/hdy.2015.5

Lavryashina, M., Ulyanova, M., Balaganskaya, O., Balanovska, E. (2016). Genetic structure of the Khakass sub-ethnic groups. From autosomal DNA markers and surnames. Science Evolution. 1(2), 78-84. https://doi.org/10.21603/2500-1418-2016-1-2-78-84

Leśniewska, D. (2004). Kolonizacja niemiecka i na prawie niemieckim w średniowiecznych Czechach i na Morawach w świetle historiografii. Poznań: Poznańskie Towarzystwo Przyjaciół Nauk.

Lübke, Ch. (Ed.). (1998). Struktur und Wandel im Früh- und Hochmittelalter: eine Bestandsaufnahme aktueller Forschungen zur Germania Slavica. Stuttgart: Franz Steiner Verlag.

Lübke, Ch. (2014). Von der ,Sclavinia' zur Germania Slavica: Akkulturation und Transformation. In R. Härtel (Ed.). Vorträge und Forschungen, 78: Akkulturation im Mittelalter (pp. 207-234). Ostfildern: Jan Thorbecke Verlag.

Mally, A.K. (1974). "Piefke“. Herkunft und Rolle eines österreichischen Spitznamens für den Preußen, den Nord- und den Reichsdeutschen. Muttersprache. Zeitschrift zur Pflege und Erforschung der deutschen Sprache, 84(4), 257-286.

Malyarchuk, B.A., Grzybowski, T., Derenko, M.V., Czarny, J., Woźniak, M., Miścicka-Sliwka, D. (2002). Mitochondrial DNA variability in Poles and Russian. Annals of Human Genetics, 66, 261-283. https://doi.org/10.1046/j.1469-1809.2002.00116.x

Malyarchuk, B., Derenko, M. (2001). Mitochondrial DNA variability in Russians and Ukrainians: Implication to the origin of the Eastern Slavs. Annals of Human Genetics, 65, 63-78. https://doi.org/10.1046/j.1469-1809.2002.00116.x

Małowist, M. (2010). Western Europe, Eastern Europe and world development, 13th-18th centuries. Leiden - Boston: Haymarket Books,.

Matulevičius, A. (2019). Mažosios Lietuvos ir lietuvininkų fenomenas Europos kultūroje. Kaunas: Naujasis lankas.

Meinecke, F. (2016). Prusy i Niemcy w XIX w. In H.-J. Bomelburg, A. Lawaty (Eds.), Prusy - mity i rzeczywistość (pp. 259-272). Poznań: Nauka i Innowacje.

Mielnik-Sikorska, M., Daca, P., Woźniak, M., Malyarchuk, B.A., Bednarek, J., Dobosz, T., Grzybowski, T. (2013). Genetic data from Y chromosome STR and SNP loci in Ukrainian population. Forensic Science International: Genetics, 7, 200-203. https://doi.org/10.1016/j.fsigen.2012.05.007

Moeller van den Bruck, A. (2016). Pruski styl. In H.-J. Bomelburg, A. Lawaty (Eds.), Prusy - mity i rzeczywistość (pp. 285-298). Poznań: Nauka i Innowacje.

Muka, K.A. (1904). Szczątki języka połabskiego Wendów Luneburskich. Materiały i prace Komisyi Językowej Akademii Umiejętności w Krakowie, 1, 313-569.

Neparáczki, E., Maróti, Z., Kalmár, T., Maár, K., Nagy, I., Latinovics, D., ... Balogh, C. (2019). Y-chromosome haplogroups from Hun, Avar and conquering Hungarian period nomadic people of the Carpathian Basin. Scientific Reports, 9. https://doi.org/10.1038/s41598-019-53105-5 [5 May 2020].

Niederstätter, H., Rampl, G., Erhart, D., Pitterl, F., Oberacher, H., Neuhuber, F., Hausner, I., Gassner, Ch., Schennach, H., Berger, B., Parson, W. (2012). Pasture names with romance and Slavic roots facilitate dissection of $Y$ chromosome variation in an exclusively German-speaking Alpine region. PLOS ONE, 7(7): e41885. https://doi.org/10.1371/journal.pone.0041885.

North, M. (2015). Geschichte Mecklenburg-Vorpommerns. München: C.H.Beck. 
Pliss, L., Timša, L., Rootsi, S., Tambets, K., Pelnena, I., Zole, E., ... Kucinskas, V (2015). Y-Chromosomal Lineages of Latvians in the Context of the Genetic Variation of the Eastern-Baltic Region. Annals of Human Genetics, 79(6), 418-430. https://doi.org/10.1111/ahg.12130

Piskorski, J.M. (2005). Kolonizacja wiejska Pomorza Zachodniego w XIII i w początkach XIV wieku na tle procesów osadniczych w średniowiecznej Europie. Poznań: Poznańskie Towarzystwo Przyjaciół Nauk.

Poetsch, M., Wittig, H., Krause, D., Lignitz, E. (2003). Mitochondrial diversity of a northeast German population sample. Forensic Science International, 137, 125-132.

https://doi.org/10.1016/j.forsciint.2003.06.001

Pol, W. (1989). Na lodach; Na wyspie; Na groblach: trzy obrazki znad Bałtyku. Gdańsk: Wydawnictwo Morskie.

Putzger, F.W., Baldamus, A., Koch, J., Schwabe, E. and others (1893). Historischer Schul-Atlas. Bielefeld - Leipzig: Velhagen \& Klasing.

Quintana-Murci, L., Harmant, Ch., Quach, H., Balanovsky, O., Zaporozhchenko, V., Bormans, C., van Helden, P.D., Hoal, E.G., Behar, D.M. (2010). Strong maternal Khoisan contribution to the South African coloured population: A case of gender-biased admixture. The American Journal of Human Genetics, 86, 611-620. https://doi.org/10.1016/j.ajhg.2010.03.015

Reich, D. (2019). Kim jesteśmy, skąd przyszliśmy...: kopalny DNA i nowa nauka o przeszłości człowieka. Stare Groszki: Wydawnictwo CiS.

Reif, H. (1994). Ostelbische Agrargesellschaft im Kaiserreich und in der Weimarer Republik: Agrarkrise-junkerliche Interessenpolitik-Modernisierungsstrategien. Berlin: Akademie-verlag,.

Rębała, K., Mikulich, A.I., Tsybovsky, I.S., Siváková, D., Džupinková, Z., Szczerkowska-Dobosz, A., Szczerkowska, Z. (2007). Y-STR variation among Slavs: Evidence for the Slavic homeland in the Middle Dnieper Basin. Journal of Human Genetics, 52(5), 406-414. https://doi.org/10.1007/s10038-007-0125-6

Rębała, K., Tsybovsky, I.S., Mikulich, A.I., Szczerkowska, Z. (2012). Identyfikacja polimorfizmu typu Y-SNP w genie USP9Y i jego znaczenie w genotypowaniu alleli locus M46. Archiwum Medycyny Sadowej i Kryminologii, 62, 165-170.

Rębała, K., Martínez-Cruz, B., Tönjes, A., Kovacs, P., Stumvoll, M., Lindner, I., Büttner, A., Wichmann, H.-E., Siváková, D., Soták, M., Quintana-Murci, L., Szczerkowska, Z., Comas, D., The Genographic Consortium (2013). Contemporary paternal genetic landscape of Polish and German populations: from early medieval Slavic expansion to post-World War II resettlements. European Journal of Human Genetics, 21(4), 415-422. https://doi.org/10.1038/ejhg.2012.190

Rodig, H., Grum, M., Grimmecke, H.-D. (2007). Population study and evaluation of 20 Y-chromosome STR loci in Germans. International Journal of Legal Medicine, 121, 24-27.

https://doi.org/10.1007/s00414-005-0075-5

Rudnicki, M. (1936). Nadolny Rudolf. Germanísíerung oder Slavisierung. Slavia Occidentalis, 15, 211-250.

Rutkowski, J. (1953). Historia gospodarcza Polski do 1864 r. Warszawa: Książka i Wiedza.

Rykiel, Z. (1986). Ograniczenia meldunkowe jako bariery przestrzenne. Przeglad Geograficzny, 58(3), 395-409.

Sakson, A. (1994). Polska, Niemcy, mniejszość niemiecka w Wielkopolsce: przeszłość i teraźniejszość. Poznań: Instytut Zachodni.

Salmonowicz, S. (1987). Prusy, dzieje państwa i społeczeństwa. Poznań: Wydawnictwo Poznańskie.

Schich, W., Stephan, J. (2015). Strukturalne przemiany na Śląsku wywołane akcją kolonizacyjną na przykładzie biskupiego księstwa nyskiego. Studia Geohistorica, 3, 205-218

Scott, J.W. (2018). Border politics in Central Europe: Hungary and the role of national scale and nationbuilding. Geographia Polonica, 91(1), 17-32. https://doi.org/10.7163/gpol.0101

Scozzari, R., Massaia, A., D’Atanasio, E., Myres, N.M., Perego, U.A., Trombetta, B., Cruciani, F. (2012). Molecular dissection of the basal clades in the human Y chromosome phylogenetic tree. PLOS ONE, 7(11): e49170. https://doi.org/10.1371/journal.pone.0049170. 
Szczepankiewicz-Battek, J. (2005). Łużyce - przestrzeń dysocjacji kultur narodowych i religijnych. Słupsk: Pomorska Akademia Pedagogiczna w Słupsku.

Siatkowski, J. (2015). Historia badań nad wpływami słowiańskimi na język niemiecki. Gwary Dziś, 7, 141-154.

Siwek, T. (2012). Inner divisions of the Czech Republic. Geographia Polonica, 85(1), 23-31. https://doi.org/10.7163/gpol.2012.1.2

Skowronek, J., Tanty, M., Wasilewski, T. (1988). Historia Stowian południowych i zachodnich. Warszawa: PWN.

Skóra, W. (2004). Kaszubi bytowscy i lęborscy w świetle opracowania urzędnika MSZ II Rzeczypospolitej z 1930 roku. Acta Cassubiana, 4, 295-336.

Smólski, G. (1911). Z podróży na Pomorze, 7. Ziemia, 2(40), 557-660.

Sobczyński, M. (2008). Polskie doświadczenia w zakresie badania granic reliktowych i krajobrazu pogranicza. In M. Kulesza (ed.), Czas i przestrzeń w naukach geograficznych: Wybrane problemy geografii historycznej (pp. 66-78). Łódź: Wydawnictwa Uniwersytetu Łódzkiego.

Sosnowska, A. (2004). Zrozumieć zacofanie. Spory historyków o Europę Wschodnią (1947-1994). Warszawa: Trio.

Srokowski, S. (1937). Ludność Prus Wschodnich. Warszawa: Bellona.

Stawecki, P., Wrzesiński, W. (Ed.) (1986). Plebiscyty na Warmii, Mazurach i Powiślu w 1920 roku: wybór źródeł. Olsztyn: Ośrodek Badań Naukowych im. Wojciecha Kętrzyńskiego.

Stepanova, S.V. (2019). The Northern Ladoga region as a prospective tourist destination in the RussianFinnish borderland: Historical, cultural, ecological and economic aspects. Geographia Polonica, 92(4), 409-428.

Strzelczyk, J. (1976a). Stowianie i Germanie u Niemczech środkowych we wczesnym średniowieczu. Poznań: Poznań: Wydawnictwo Naukowe UAM.

Strzelczyk, J. (1976b). Słowianie koło Erfurtu. Slavia Antiqua, 23, 211-228.

Strzelczyk, J. (1981). Problemy badań nad zachodnia peryferiq osadnictwa słowiańskiego w Niemczech. In J. Strzelczyk (Ed.), Słowiańszczyzna Połabska między Niemcami a Polska (pp. 183-199), Poznań: Wydawnictwo Naukowe UAM.

Sykes, B. (2007). Przekleństwo Adama. Przyszłość bez mężczyzn. Warszawa: Prószyński i Spółka.

Śladkowski, W. (1969). Kolonizacja niemiecka w południowo-wschodniej części Królestwa Polskiego w latach 1815-1915. Lublin: Wydawnictwo Lubelskie.

Šołta, J. (1984). Zarys dziejów Serbołużyczan. Wrocław: Ossolineum.

Tetushkin, E. Ya. (2011). Genetic genealogy: History and methodology. Russian Journal of Genetics, 47(5), 1-14. https://doi.org/10.1134/s1022795411040132

Teztner, F. (1902). Die Slawen in Deutschland. Braunschweig: F. Vieweg und sohn.

Underhill, P.A., Poznik, G.D., Rootsi, S., Järve, M., Lin, A.A., Wang, J., ... Di Cristofaro, J. (2014). The phylogenetic and geographic structure of Y-chromosome haplogroup R1a. European Journal of Human Genetics, 23(1), 124-131. https://doi.org/10.1038/ejhg.2014.50

Veeramah, K.R., Tönjes, A., Kovacs, P., Gross, A., Wegmann, D., Geary, P., Gasperikova, D., Klimes, I., Scholz, M., Novembre, J., Stumvoll, M. (2011). Genetic variation in the Sorbs of eastern Germany in the context of broader European genetic diversity. European Journal of Human Genetics, 19(9), 995-1001. https://doi.org/10.1038/ejhg.2011.65

Watson, J.D., Berry, A., Davies, K. (2018). DNA. Historia rewolucji genetycznej. Warszawa: Wydawnictwo CiS.

Wagner, P. (2005). Bauern, Junker und Beamte. Lokale Herrschaft und Partizipation im Ostelbien des 19. Jahrhunderts. Göttingen: Wallstein,.

Weber, M. (1993). Entwickelungstendenzen in der Lage der ostelbischen Landarbeiter (1894). In M. Weber, Gesamtausgabe, I, 4, 1 (pp. 362-462), Tübingen: Mohr Siebeck. 
von Wedel, J. (2011). „Landarbeiterenquete” Maxa Webera a transformacja z roku 1990. Przeglad Zachodniopomorski, 26(3), 165-177.

Weiher, G.R. (1991). Fractured metropolis: Political fragmentation and metropolitan segregation. Albany: State University of New York Press.

Więckowski, M. (2018). Political borders under ecological control in the Polish borderlands. Geographia Polonica, 91(1), 127-138. https://doi.org/10.7163/gpol.0105

Więckowski, M. (2019). Od barier i izolacji do sieci i przestrzeni transgranicznej - konceptualizacja cyklu funkcjonowania granic państwowych. Przegląd Geograficzny, 91(4), 443-466. https://doi.org/10.7163/przg.2019.4.1

Wolski, J. (Ed.) (1986). Atlas historyczny świata. Warszawa - Wrocław: PPWK.

Zabrocki, L. (1961). Transpozycje strukturalne prusko-polsko-niemieckie w zakresie nazw topograficznych Pomorza Mazowieckiego. In W. Taszycki, (Ed.), I Międzynarodowa Slawistyczna Konferencja Onomastyczna w Krakowie w dniach 22-24 października 1959. Księga referatów (pp. 201-232). Wrocław - Warszawa - Kraków: PWN.

Zastera, J., Roewer, L., Willuweit, S., Sekerka, P., Benesova, L., Minarik, M. (2010). Assembly of a large Y-STR haplotype database for the Czech population and investigation of its substructure. Forensic Science International: Genetics, 4, e75-e78. https://doi.org/10.1016/j.fsigen.2009.06.005 